\title{
An Overview of the Greek Islands' Autonomous Electrical Systems: Proposals for a Sustainable Energy Future
}

\author{
Nikolas M. Katsoulakos \\ Metsovion Interdisciplinary Research Center, National Technical University of Athens, Athens, Greece \\ Email: katsoulakos@metal.ntua.gr
}

How to cite this paper: Katsoulakos, N.M. (2019) An Overview of the Greek Islands' Autonomous Electrical Systems: Proposals for a Sustainable Energy Future. Smart Grid and Renewable Energy, 10, 55-82. https://doi.org/10.4236/sgre.2019.104005

Received: March 7, 2019

Accepted: April 14, 2019

Published: April 17, 2019

Copyright $\odot 2019$ by author(s) and Scientific Research Publishing Inc. This work is licensed under the Creative Commons Attribution International License (CC BY 4.0).

http://creativecommons.org/licenses/by/4.0/

\section{c) (i) Open Access}

\begin{abstract}
Among the Greek islands, 61 are based-currently-on autonomous electrical systems for covering the electrical energy demand and are characterized as Non-Interconnected Islands (NII). The average electricity production cost in the NII is 2.5 times higher than in areas with access to the main, interconnected electricity grid (IEG) of Greece. In this paper, an analytic overview of the autonomous electricity systems of Greek islands is provided, focusing on electricity consumption and production, as well as on the relative costs. For investigating possibilities for improving the situation, especially in small, remote islands, simulations for the energy system of Astypalea are conducted. It is proved that further use of renewables in combination with energy storage can lower the current, high energy costs. Expansion of the IEG is not economically viable for islands which are far away from the mainland and their peak loads are less than $10 \mathrm{MW}$.
\end{abstract}

\section{Keywords}

Greek Islands, Autonomous Energy Systems, High Energy Costs, Energy

Optimization, Astypalea

\section{Introduction}

The great number of islands and the extensive mountain ranges are distinctive features of Greece's natural geography. The Constitutional Law of the country includes a special reference (Article 101, paragraph 4) to island and mountain territories: "The common Legislator and the Administration, when setting regulations, are obliged to consider the particular circumstances of island and mountain areas, catering for the development of these areas" [1]. The author has 
been systematically involved in research regarding the particularities of energy planning in mountainous areas [2] [3] [4]. Considering Greece's geography, as well as the necessity for setting up specialized strategies both for mountains and islands in the country, the present work is aiming at identifying energy policies for the Greek islands.

As regards the islands some more specific facts, following the data provided by the Hellenic Statistical Authority (HSA), are the following [5]:

- The total area of Greek islands represents about $15 \%$ of the total area of the country, not including Euboea.

- The total number of islands exceeds 2500 , but only about 165 of them are inhabited.

- The total population of Greek islands represents about $12 \%$ of the total population of the country $(1,339,166$ inhabitants, not including Euboea).

- Crete, Rhodes, Corfu and Lesvos gather almost 70\% of the islands' population; more than 40 islands have populations less than 1000 persons.

- Greek islands are particularly important for the Greek economy; Crete, Rhodes, Corfu, Mykonos, Santorini (Thira), Paros are some of the most popular touristic destinations, at global level.

Many of the islands are far away from the mainland. So, they need to be electrified by autonomous electrical systems and grids. These islands are defined as Non-Interconnected Islands (NII) by the Greek legislation and the Regulatory Authority of Energy (RAE). The NII, according to the Hellenic Electricity Distribution Network Operator (HEDNO), have four main characteristics [6]:

1) They differ significantly in area and population and, in many cases, they are not easily accessible, especially from the sea.

2) They have abundant renewable energy potential, particularly wind and solar energy potential.

3) They cannot exchange electricity with other electrical systems, and this affects the reliability and security of energy supply.

4) Since they are not interconnected with electrical systems of high inertia, there are problems regarding stability of voltage and frequency, particularly in cases of high penetration rates of intermittent renewable energy sources (RES).

HDNO, as operator of the NII systems electrical grids, has set some strategic aims for improving the current situation in these off-grid electrical systems. Until 2020, it is planned to: 1) complete the basic infrastructure of HDNO in the NII, 2) to enhance the infrastructure of NII regarding energy monitoring and metering, 3) upgrade the energy market in the NII and, 4) complete pilot projects of energy autonomous islands, which will set up the basis for the energy future of NII [6]. Basic part of these strategic aims is the interconnection of the NII to the electrical grid of mainland Greece, wherever this is possible.

The paper provides a broad view of the electrical systems of the NII and their characteristics and investigates possibilities for upgrading autonomous electrical systems in a sustainable way. Although the literature regarding energy in the Greek islands is not poor, e.g. [7] [8] [9], an overall examination of the energy 
landscape in the NII is missing from the bibliography. Therefore, the present paper tries to provide this overview by combining data related to the NII found retained by different bodies, like HDNO, RAE, HSA etc. Some further useful conclusions are reached by correlations between parameters of the energy data of the NII. Then, the island of Astypalea, which is a representative example of small-scale autonomous electrical system operation, is used as a case study, in order to investigate solutions that will improve the future perspectives of NII in the energy sector. To do so, optimization of Astypalea energy system is conducted and various solutions are tested. Hence, the paper is an integrated approach to the NII electrical systems, since it combines analysis of secondary data with energy planning optimization, in order to draw policy conclusions.

The data and methodology used for composing the present paper are presented in Section 2. The characteristics of the NII electrical systems, the statistical analysis of the corresponding data and the findings from energy optimization in the island of Astypalea are included in Section 3. In Section 4 estimations regarding the interrelation of the study's results with energy policy are mentioned. Finally, in Section 5 the most important points of the paper are summarized, and conclusions are extracted.

\section{Materials and Methods}

In order to gain a broad view of the Greek NII electrical systems, firstly, data were collected. The necessary data were retrieved, mainly, from HEDNO, which has given public access to the following information for the NII:

- Electricity production, at monthly basis, from thermal stations (years 2014 to 2017).

- Electricity production, at monthly basis, from renewable energy plants (years 2014 to 2017).

- Variable cost of electricity production, at monthly basis (years 2014 to 2017).

- Total cost of electricity production, at monthly basis (years 2014 to 2017).

Data related to the installed power capacity of the NII energy units were collected both from HEDNO and RAE. The HSA was the main source for demographic and socioeconomic data for the NII. The Operator of the Electricity Market (OEM) was the source of data regarding: 1) electricity consumption in the whole of the country, and 2) marginal price of electricity production in the Interconnected Grid.

The statistical analysis of the NII electrical systems characteristics was conducted by using Microsoft Excel (for simple statistical analysis and graphs' composition) and SPSS/Statistical Package for the Social Sciences (for correlation and regression analysis).

As far as the optimization of Astypalea electrical system is concerned, hourly load data were provided by HDNO, for the years 2014 and 2015. The optimization was realized by using HOMER software (version PRO x64). HOMER's goal is to find the least cost combination of equipment for consistently meeting the 
electric load [10]. Main aim of the energy optimization in Astypalea was to explore ways to decrease the current high electricity production costs, with parallel increase in the share of renewables. To this direction, the objectives of the procedure were:

- Testing how various combinations of energy sources and energy storage systems can lower the energy cost and footprint of the local energy system.

- Checking the feasibility of grid expansion from the mainland to the island of Astypalea.

- Conducting sensitivity analysis with respect to various important parameters of the energy system.

In order to validate the reliability of the optimization software and the general assumption that were made, the current main elements (diesel generators, photovoltaic array, diesel oil price etc.) of Astypalea's electrical systems were entered into HOMER and the optimization results led to a solution very close to the actual situation of the local energy system.

\section{Results and Discussion}

\subsection{Energy Production Units in the Non-Interconnected Islands}

The energy production cluster of NII is composed by 32 autonomous electrical systems, which provide electricity to 61 islands, which are shown in Table 1, as well as their permanent population, according to the census of the Hellenic Statistical Authority [11]. The production of electricity is based on thermal stations, which operate with heavy oil (mazut) or light oil (diesel). The installed capacity of the NII thermal stations is presented in Table 2. In total, during 2017, the installed capacity was $1808.35 \mathrm{MW}$ [12]. In addition, renewable energy plants are operating in many of the NII, whose capacity is also shown in Table 2. The total capacity of RES station in the NII was $459.59 \mathrm{MW}$ in the first four months of 2018. Regarding shares in energy consumption, $81.5 \%$ of it is covered by thermal stations and $18.5 \%$ by RES stations. The RES share is distributed as follows:

- $60.7 \%$ wind power.

- $34.3 \%$ solar power (photovoltaic stations).

- $4.7 \%$ solar power (rooftop photovoltaics and net-metering).

- $0.3 \%$ from other RES (this is the estimated contribution to RES energy from a small hydro-station with nominal capacity of $0.3 \mathrm{MW}$ and a small biogas unit with nominal capacity $0.5 \mathrm{MW}$, which are operating in Crete).

It is noted that an important characteristic of the NII energy systems is the use of generators (mainly diesel powered) for covering extra, seasonal needs in electricity. The generators are as a rule rented by the energy producers and transported to the islands. This, of course, causes increases in energy production costs and will be further analyzed in Section 3.3. The management of the energy market in the NII is made by the Hellenic Electricity Distribution Network Operator S.A. (HEDNO). A general categorization of the 32 autonomous electrical systems of the NII is the following: 
- 19 electrical systems are small-sized, with peak loads less than $10 \mathrm{MW}$.

- 10 electrical systems are medium-sized, with peak loads between 10 and 100 MW.

- 3 electrical systems are big-sized, with peak loads more than $100 \mathrm{MW}$ (the ones of Crete, Rhodes and Kos-Kalymnos).

Table 1. Energy systems of NII and population served by them [11] [13].

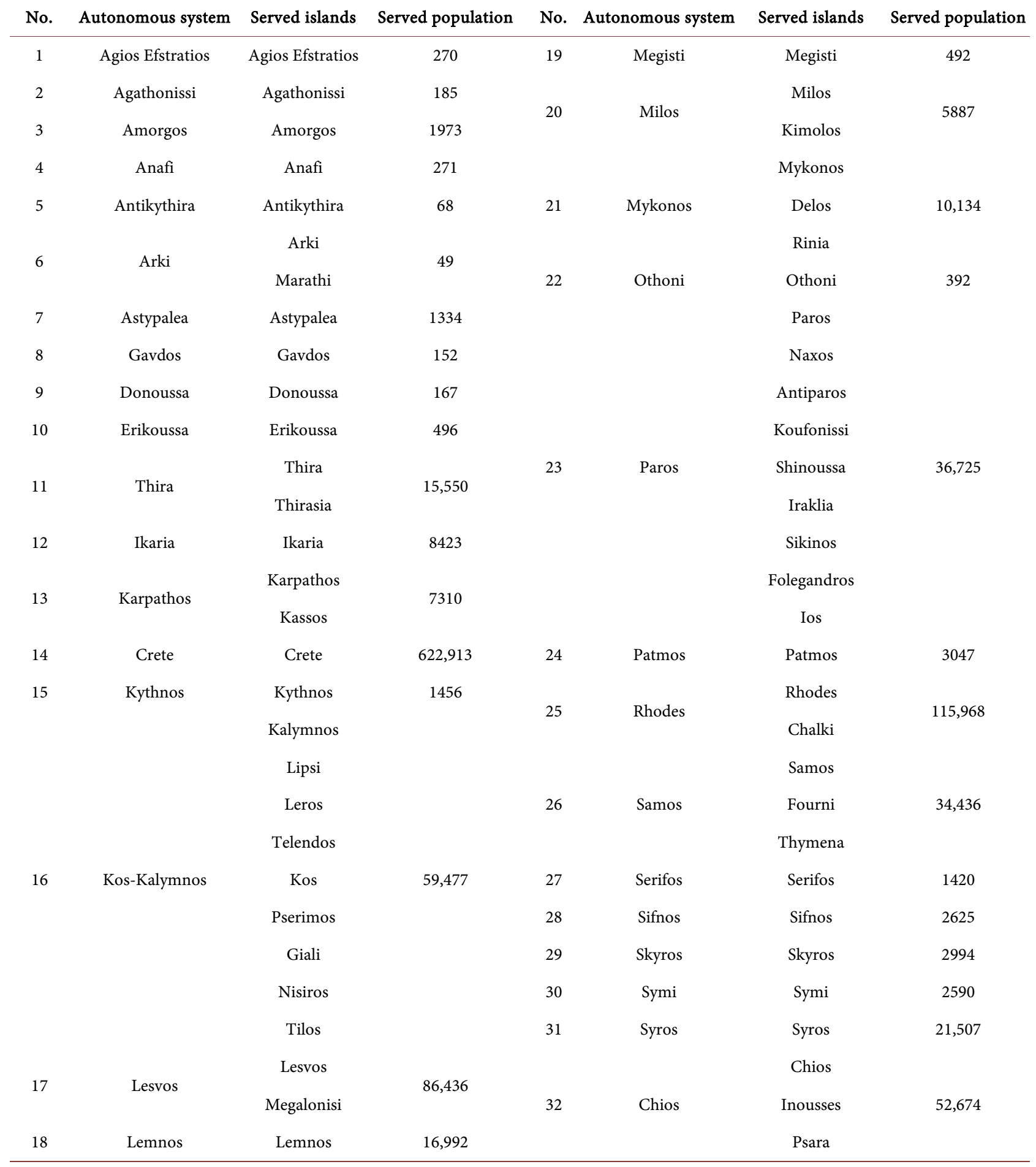


Table 2. Installed capacity of thermal and RES stations in the NII-year 2017 [12].

\begin{tabular}{|c|c|c|c|c|c|}
\hline NII System & $\begin{array}{l}\text { Capacity of thermal } \\
\text { stations (MW) }\end{array}$ & $\begin{array}{c}\text { Capacity of RES } \\
\text { stations (MW) }\end{array}$ & NII System & $\begin{array}{l}\text { Capacity of thermal } \\
\text { stations (MW) }\end{array}$ & $\begin{array}{l}\text { Capacity of RES } \\
\text { stations (MW) }\end{array}$ \\
\hline Agios Efstratios & 0.84 & 0.02 & Lesvos & 94.88 & 22.79 \\
\hline Agathonissi & 0.64 & 0.00 & Lemnos & 23.60 & 4.93 \\
\hline Amorgos & 6.20 & 0.29 & Megisti & 1.73 & 0.00 \\
\hline Anafi & 1.15 & 0.00 & Milos & 22.98 & 3.27 \\
\hline Antikyhtira & 0.41 & 0.00 & Mykonos & 67.49 & 2.24 \\
\hline Arkioi & 0.41 & 0.00 & Othoni & 0.66 & 0.66 \\
\hline Astypalea & 3.83 & 0.32 & Paros & 93.72 & 17.07 \\
\hline Gavdos & 0.43 & 0.00 & Patmos & 8.93 & 1.35 \\
\hline Dosnoussa & 0.99 & 0.00 & Rhodes & 232.93 & 66.71 \\
\hline Erikoussa & 0.77 & 0.00 & Samos & 49.63 & 12.75 \\
\hline Thira & 75.09 & 0.25 & Serifos & 6.69 & 0.10 \\
\hline Ikaria & 15.89 & 1.39 & Sifnos & 11.48 & 0.20 \\
\hline Karpathos & 16.50 & 2.39 & Skyros & 8.45 & 0.32 \\
\hline Crete & 796.82 & 279.38 & Symi & 8.60 & 0.19 \\
\hline Kythnos & 5.92 & 0.91 & Syros & 39.25 & 3.83 \\
\hline Kos-Kalymnos & 133.66 & 23.98 & Chios & 77.78 & 14.25 \\
\hline
\end{tabular}

\subsection{Electrical Energy Consumption and Production in the NII}

According to the data published by HDNO for the years 2014-2017 (48 months, in total), the electrical energy consumption and production of all the electrical systems of the NII can be summarized as follows:

- Average, annual consumption: 5,672,339 MWh (standard deviation equal to $176,854.15 \mathrm{MWh}$ or $3.12 \%)$.

- Average, annual electricity production from thermal stations: 4,643,288 MWh (standard deviation equal to 144,617.78 MWh or 3.11\%).

- Average, annual electricity production from RES: 1,029,051 MWh (standard deviation equal to $60,363.98$ MWh or 5.87\%).

The electricity consumption of the NII corresponds to about $10 \%$ of the total electricity consumption of Greece [14].

The total, average electrical energy consumption in the NII is presented in Figure 1, as well as the electricity consumption of the three biggest autonomous systems (Crete, Rhodes, Kos-Kalymnos). It is notable that these three systems represent, in average, $73 \%$ of the total energy consumption of all 31 autonomous NII systems.

The electricity consumption is maximized during August (692,969 MWh) and minimized during November $(356,109 \mathrm{MWh})$. The maximum monthly consumption is $95 \%$ higher than the minimum one. This illustrates one of the most distinctive characteristics among the electrical systems of the NII. The population in many islands increases during the summer due to tourism. So, great 
fluctuations are observed in the energy consumption. In the case of Mykonos, an island famous worldwide for summer tourism, in August the electricity consumption is $362 \%$ higher than in November (Figure 2). Because of the population increase during the summer, in many cases, the installed capacity of power stations is much greater than the capacity needed for the permanent inhabitants of the islands. This is reflected in the installed capacity per capita; in the NII the installed electricity capacity per capita is $21 \%$ higher than in mainland Greece, served by the interconnected electricity network [14]. In the case of Mykonos, the installed capacity per capita is $390 \%$ higher than the average in mainland Greece. The lowest fluctuation in electricity consumption is noticed in the case of Lesvos (55\%), whose economy is not exclusively based on tourism. This value of fluctuation in electricity consumption is similar to the one of the IEG [15]. In Table S1 of the Appendix, the average electricity production from thermal stations and RES per month for the period 2014-2017, in each of the NII systems is presented.

In Table 3 the average production from thermal and power stations per month in each NII is presented. The great differences in electricity consumption between the several NII is clearly shown in this Table. The thermal station of the autonomous system of Antikythira produces, in average, 21.54 MWh, whereas the mean production of Crete's thermal stations exceeds 190,000 MWh. Such great differences in energy demand imply that there is no a single way for managing and improving the energy systems in the NII. On the contrary, specialized strategies, adopted to local differentiations should be developed.

Table 3. Average, monthly electrical energy consumption from thermal and RES station in the NII.

\begin{tabular}{cccccc}
\hline NII System & $\begin{array}{c}\text { Thermal stations } \\
\text { production (MWh) }\end{array}$ & $\begin{array}{c}\text { RES stations } \\
\text { production (MWh) }\end{array}$ & NII System & $\begin{array}{c}\text { Thermal stations } \\
\text { production (MWh) }\end{array}$ & $\begin{array}{c}\text { RES stations } \\
\text { production (MWh) }\end{array}$ \\
\hline Agios Efstratios & 92.13 & 0.00 & Lesvos & $20,597.55$ & 3986.49 \\
Agathonissi & 58.84 & 0.00 & Lemnos & 4342.31 & 633.13 \\
Amorgos & 793.72 & 40.83 & Megisti & 278.55 & 0.00 \\
Anafi & 105.33 & 0.00 & Milos & 3636.21 & 664.94 \\
Antikyhtira & 21.54 & 0.00 & Mykonos & $10,777.76$ & 381.94 \\
Arkioi & 29.38 & 0.00 & Othoni & 52.34 & 0.00 \\
Astypalea & 521.76 & 49.12 & Paros & $14,660.81$ & 3346.14 \\
Gavdos & 40.33 & 0.00 & Patmos & 1278.44 & 198.54 \\
Dosnoussa & 70.52 & 0.00 & Rhodes & $56,264.58$ & $10,647.98$ \\
Erikoussa & 66.69 & 0.00 & Samos & 9178.84 & 2329.30 \\
Thira & $13,167.48$ & 84.98 & Serifos & 753.72 & 18.03 \\
Ikaria & 2066.08 & 260.04 & Sifnos & 1548.54 & 49.18 \\
Karpathos & 2743.18 & 381.94 & Skyros & 1271.19 & 41.72 \\
Crete & $191,659.30$ & $55,655.12$ & Symi & 1190.19 & 22.65 \\
Kythnos & 761.76 & 32.53 & Syros & 7354.03 & 611.73 \\
Kos-Kalymnos & $26,699.95$ & 3980.96 & Chios & $14,857.64$ & 2336.94 \\
\hline
\end{tabular}




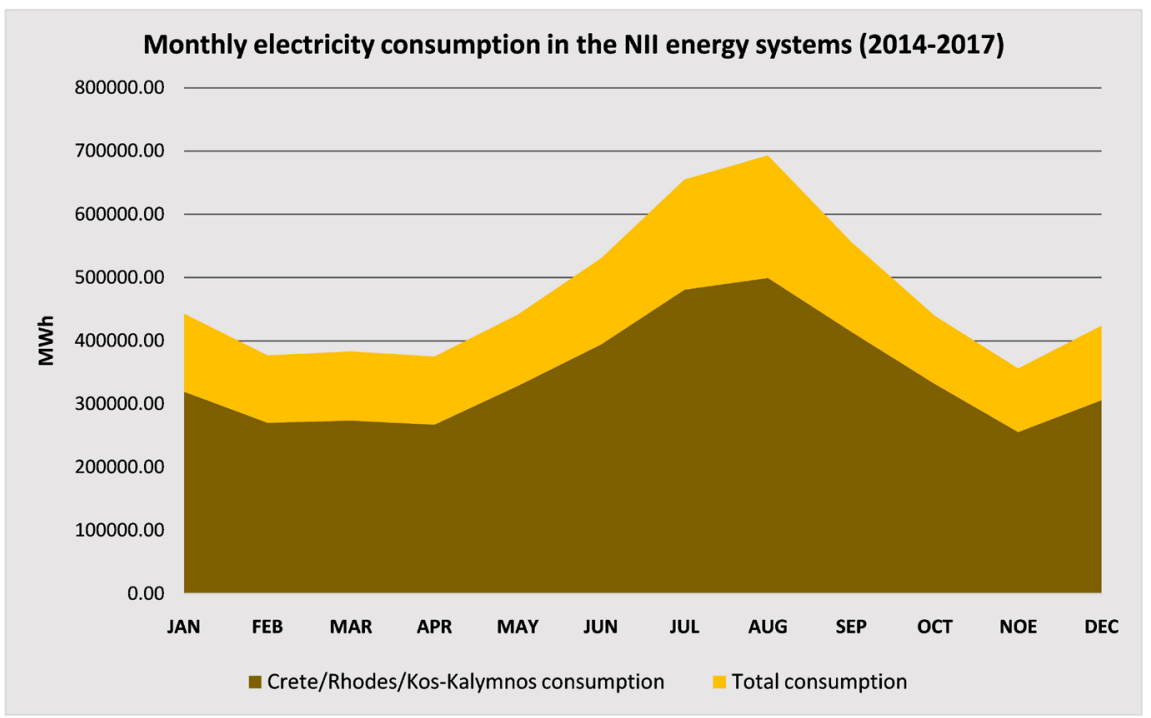

Figure 1. Electrical energy consumption in the NII energy systems during the period 2014-2017.

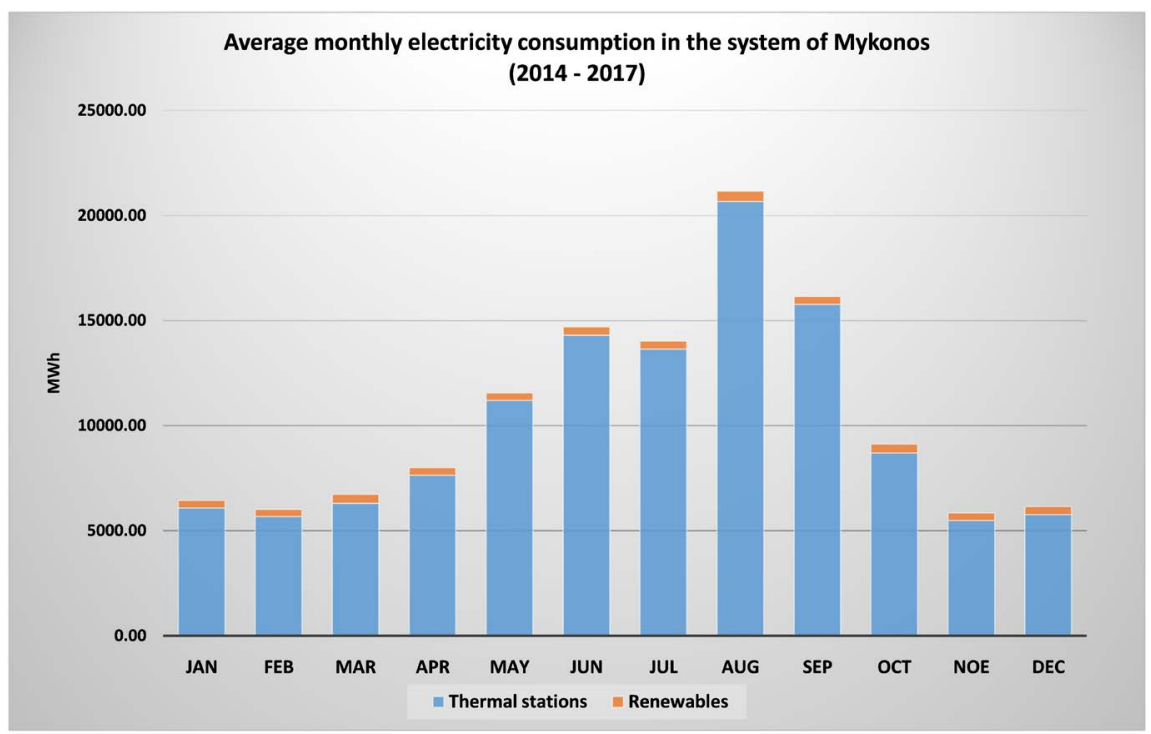

Figure 2. Average monthly electrical energy consumption in the energy system of Mykonos during the period 2014-2017.

\subsection{Energy Costs in the NII Electrical Systems}

Maybe, the most distinctive feature of the autonomous energy systems of the Greek islands is the particularly increased cost of energy production. Besides, this is the reason that causes discussion about the necessity of changing the current situation in the islands. The great energy production cost is attributed, mainly, to two factors: 1) the thermal stations operating as base-load units use oil as fuel that is expensive, 2) the great fluctuations in energy demand that make necessary either the existence of particularly high installed capacity or the transfer of generators, in order to cover peaks of energy demand.

The high energy costs of the NII are covered by a special levy that is charged 
to all electricity consumers, called "Services for common utilities" (SCU). SCU, according to the Law 4067/2012, are intended to cover: 1) the high energy costs of NII, 2) the very low electricity charges for families with four or more children, and 3) the low electricity charges of the so called Special Social Tariff that is a special electricity tariff for households with low income. The rates of SCU are the following for domestic electricity consumers [16]:

- 6.99€/MWh-consumption up to $1600 \mathrm{kWh} / 4$ months.

- $15.70 € / \mathrm{MWh}$-consumption 1601 to $2000 \mathrm{kWh} / 4$ months.

- 39.87€/MWh-consumption 2001 to $3000 \mathrm{kWh} / 4$ months.

- $44.88 € / \mathrm{MWh}$-consumption over $3001 \mathrm{kWh} / 4$ months.

The energy production cost presents differentiations among the NII; this is something that was expected because of the great differences between the energy consumption of the various energy systems. The weighted average of the variable cost all the NII electrical systems was 130.519€/MWh, between 2014 and 2017. The greatest cost is observed in the system of Antikythira (average variable cost 383.863€/MWh), which has the smallest electricity demand and it serves the smallest population among the NII. This autonomous system does not include any RES. The system with the lowest cost is the one of Chios (92.434€/MWh), which is a medium-sized system, with a share of renewables (15.7\%), close to the average of the NII. In Figure 3, the variable cost in the NII is illustrated in descending order. The average marginal price of the interconnected electricity grid of Greece (AMPIG) is also included in Figure 4, to gain a comparative perspective. In the period 2014-2017 the average marginal cost was 51.338€/MWh [15]. The energy production in the system of Chios, with the lowest cost among the NII, is $80 \%$ more expensive than in the interconnected system. The weighted average marginal cost of the NII is 2.5 times higher than the AMPIG, and the variable cost of the Antikythira system is 7.5 higher than the AMCIS. These findings are indicative of the great economic burden of electricity in the NII and support the necessity of changing the current situation. The difference between the average variable cost in the NII and the AMPIG was $79.181 € / M W h$, as shown in Figure 4.

In the previous paragraph the term "variable cost" was used to refer to the energy production cost in the NII. According to the official definition, the variable cost of electricity in the NII, in $€ / M W h$, is given by Equation (1) [17]:

$$
M M K_{m, s}=\frac{K K_{m s}}{Q_{\Sigma \mathrm{M}, m, s}}+\mathrm{K} \Lambda_{m, s}+\frac{K P_{m, s}}{Q_{\Sigma \mathrm{M}, m, s}}
$$

where:

- $K K_{m, s}$ : Cost of fuel for electricity production, including the excise duty in $€$.

- $Q_{\Sigma M, m, s}:$ The sum of net energy produced and supplied to the grid from all thermal stations of each autonomous system (s) per month (m) in MWh.

- $\mathrm{K} \Lambda_{m, s}:$ The additional variable operational cost of thermal stations in $€ / M W h$.

- $K P_{m, s}:$ The cost of greenhouse gas emissions in $€ / \mathrm{MWh}$.

The cost of fuel is determined by Equation (2) [17]: 


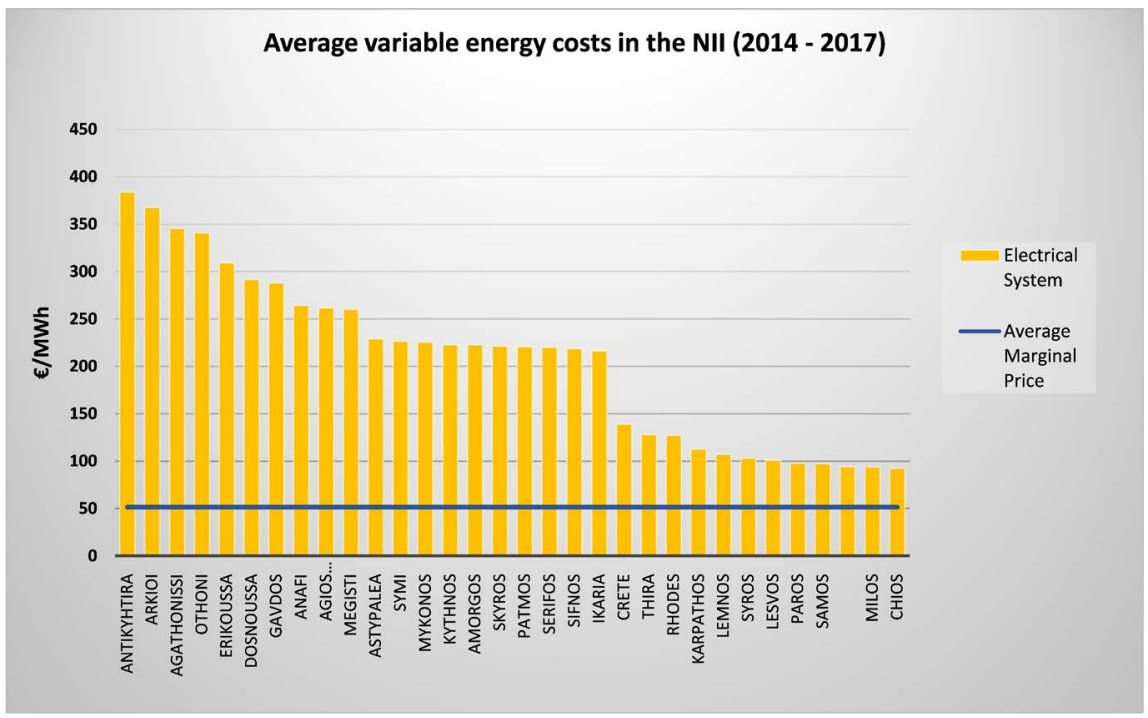

Figure 3. Average variable electrical energy production cost in the NII, in the period 2014-2017 and average marginal price of the interconnected electricity grid during the same time-period.

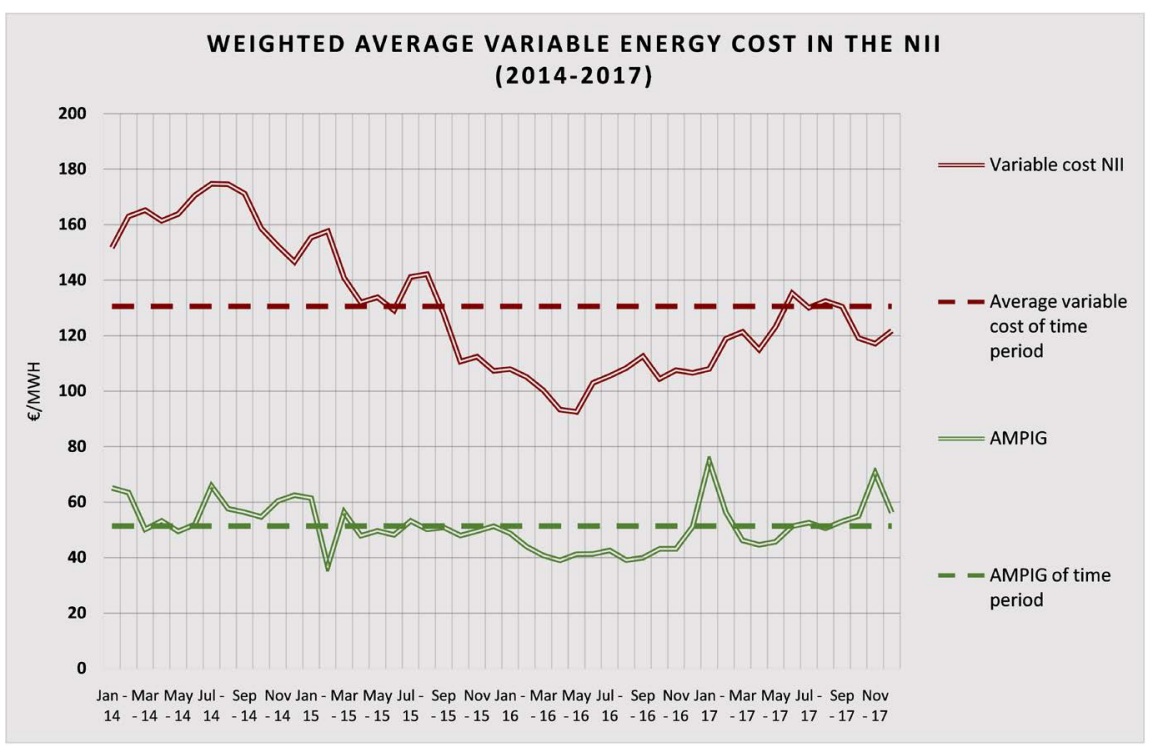

Figure 4. Weighted, average variable cost of electricity production in the NII for the years 2014-2017.

$$
K K_{m, s}=\Pi_{-} \text {mazut }_{m, s} \cdot M K_{\text {mazut } m, s}+\Pi_{\text {diesel } m, s} \cdot M K_{\text {diesel } m, s}
$$

where:

- П_mazut $t_{m, s}$, П_diesel $l_{m, s}$ : The quantities of mazut in th and diesel in klit which are expected to be consumed in the electric system (s) in the month (m).

- $M K \_$mazut $_{m, s}, M K \_$diesel $_{m, s}:$ The unit costs of mazut in $€ /$ tn and diesel in $€ /$ klit.

The variable cost is representative of the actual electricity production costs. The main factor that affects it is the fuel cost. The cost of greenhouse gas emissions is, for the time being, rather low. The relative data are not publicly accessi- 
ble for every year. Indicatively, for the year 2013, the cost of greenhouse gas emissions is known represented less than $4 \%$ of the variable energy cost of the NII. According to the available data, between 2012 and 2015, the Public Power Corporation (PPC) - which is for the time being the only energy producer in the NII-spent nearly 2.5 billion euros for purchasing mazut and diesel oil for the thermal stations of NII. The relevant data are gathered in Table 4. Hence, Figure 4 , which illustrates the weighted average variable energy cost in the NII, reflects the course of fuel prices.

According to the Regulation of NII [19], the conventional power stations receive revenues for:

- The energy they provide to the grids, based on the variable cost of electricity production and the starting cost of the power stations.

- The availability of electrical capacity (also known as cold power reserve).

- The provision of auxiliary services.

However, for the time being, the transitional provisions of the NII Regulation are being applied, since there are still pending problems for completing the reformation of the energy market of the NII. According to these transitional provisions, the energy producers that provide energy to the NII are compensated for the total energy production cost, which is defined by Equation (3) [13] [19]:

$$
M \mathrm{~K} \Pi K_{m, s}=\frac{K K_{m s}+K P_{m, s}+R A V_{m, s} \cdot r+D_{m, s}+O_{m, s}+K E A_{m, s}+E \Delta_{m, s}}{Q_{\Sigma \mathrm{M}, m, s}}
$$

where:

- $R A V_{m, s}$ "Regulated asset base", which is the sum of the non-depreciated value of fixed assets plus the working capital.

- $r$. Reasonable return on the value of the regulated asset base (defined each year by RAE).

- $D_{m, s}$ Depreciation of fixed assets.

- $O_{m, s}$ Operational expenses, namely: payroll costs, costs for maintenance and service of energy units, cost of replacement parts, insurance costs, third-parties remuneration, costs of electricity consumed by the energy units, taxes and levies.

- $K E A_{m, s}:$ Expenses for renting, transferring and installing electrical generators for covering seasonal energy needs.

- $E \Delta_{m, s}$ Shared administrative costs.

Table 4. Costs and spending on mazut and diesel oil for the thermal stations of the electrical systems of the NII [18].

\begin{tabular}{|c|c|c|c|c|c|c|c|c|}
\hline Year & $\begin{array}{c}\text { Average mazut } \\
\text { cost }(€ / \mathrm{tn})\end{array}$ & $\begin{array}{c}\text { Average diesel } \\
\text { cost }(€ / \text { klit })\end{array}$ & $\begin{array}{c}\text { Annual mazut } \\
\text { cost }(\mathrm{M} €)\end{array}$ & $\begin{array}{c}\text { Annual diesel } \\
\text { cost }(\mathrm{M} €)\end{array}$ & $\begin{array}{l}\text { Total annual } \\
\text { oil cost }(M €)\end{array}$ & $\begin{array}{l}\text { Excise duty } \\
\text { mazut }(M €)\end{array}$ & $\begin{array}{l}\text { Excise duty } \\
\text { diesel (M€) }\end{array}$ & $\begin{array}{c}\text { Total excise } \\
\text { duty (M€) }\end{array}$ \\
\hline 2012 & 548.66 & 639.30 & 499.57 & 146.65 & 646.22 & 34.6 & 75.7 & 110.3 \\
\hline 2013 & 491.57 & 599.67 & 413.89 & 130.03 & 543.92 & 31.99 & 71.56 & 103.55 \\
\hline 2014 & 459.94 & 556.52 & 395.08 & 130.87 & 525.95 & 32.64 & 77.6 & 110.24 \\
\hline \multirow[t]{2}{*}{2015} & 272.67 & 395.60 & 233.43 & 99.48 & 332.91 & 32.53 & 82.99 & 115.52 \\
\hline & Total costs & & 1541.97 & 507.03 & 2049 & 131.76 & 307.85 & 439.61 \\
\hline
\end{tabular}


The total energy production cost is, as expected, higher than the variable cost. There are cases of autonomous island systems is particularly high, mainly, due to the $K E A_{m, s}$ factor, related to seasonal needs and costs of extra electrical generators. Unfortunately, precise data regarding $K E A_{m, s}$ are not publicly available. However, fragmentary data and publications support the claim about the high values of $K E A_{m, s}$. For instance, in summer 2017, RAE approved the rental of generators with a total capacity of $37 \mathrm{MW}$ for covering seasonal loads in the NII [20]. This is certainly a big value of extra electrical capacity.

In Figure 5, the total electricity production cost of the NII for the period 2014-2017, in descendant order, is presented. In very small islands, the total cost is particularly high. In the case of Antikithyra it reached the excessive price of $1328.03 € / M W h$. Due to the low energy loads of such islands, the cost of electricity in the NII is not increased much due to the energy cost of very small islands. However, these cases are indicative of the difficulties and the high expenses for providing energy to particularly remote areas. But even in the case of Lesvos, which has the lowest total electricity production cost among the NII, the revenue of energy producers (148.967€/MWh) is almost three times higher than the revenue provided to energy producers in the interconnected energy grid of Greece. In the period 2014-2017, the weighted, average total energy cost of the NII was $186.547 € / M W h$. In other words, it was 3.6 times higher than the AMPIG during the same time period.

In Table S2 of the Appendix, the average variable and total energy production cost per month for the systems of the NII is presented.

\subsection{Statistical Correlations}

The further statistical analysis of the NII energy data includes correlations between the energy production costs and other variables. This allows the verification of basic hypotheses regarding the autonomous electrical systems of the Greek islands. So, the general directions of energy planning in the NII-aiming at improving the current situation and reducing the energy costs-can be outlined, in a robust way. The statistical calculations were made with the support of SPSS software.

Data presented in Sections 3.2 and 3.3 show that there is a cost increase tendency in small autonomous systems. This is attributed to the fact that smaller electricity systems are based on energy stations, which-as a rule-use diesel oil, which is the most expensive fuel for electricity production; in 2015, the average price of diesel oil purchased by the PPC was $0.60 € /$ lit. Moreover, the efficiency of bigger power stations is, in general, higher than the efficiency of smaller electricity generators. The correlation statistical tests verify that energy costs are related to the size of autonomous electrical systems. Specifically, both the variable and total energy production costs present:

- Strong, negative correlation with thermal plants' energy production.

- Strong, negative correlation with the installed capacity of power stations.

- Strong, negative correlation with the served population. 


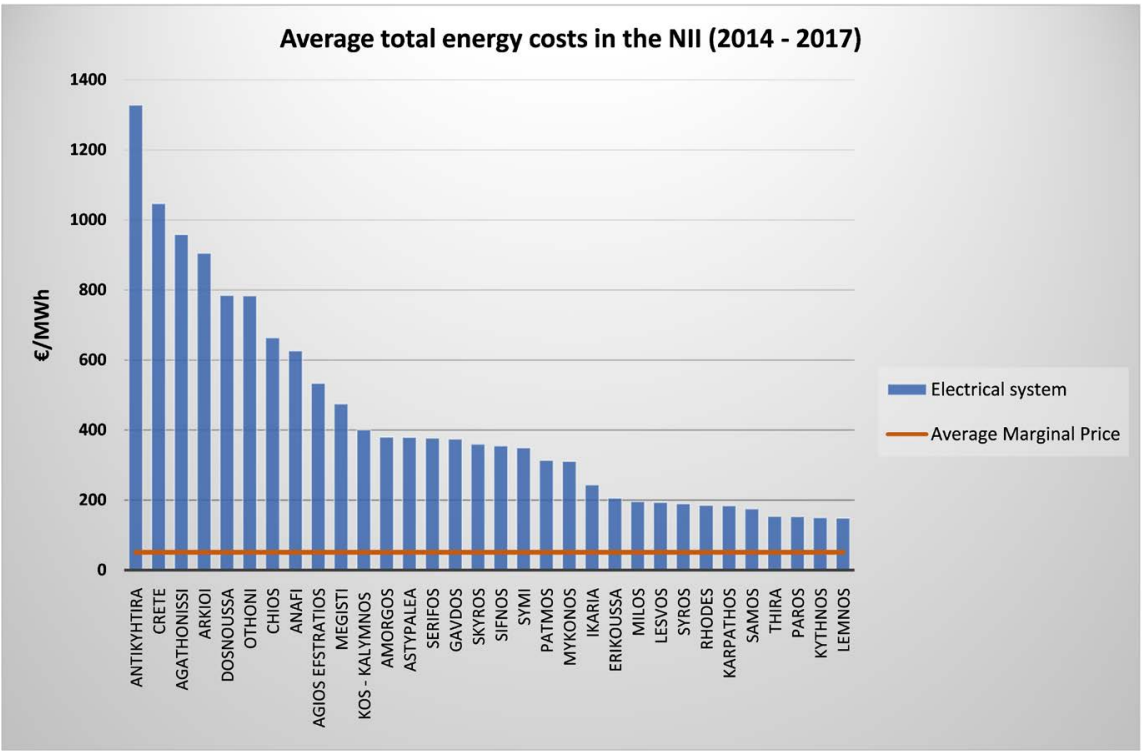

Figure 5. Average total energy production cost in the NII, in the period 2014-2017.

In Table 5 the results of the correlations between these parameters are shown. As it can be seen in Table 5, the correlations are significant at a confidence level of $99 \%$. The values of Spearman coefficient are high, over 0.85 , at absolute values, in all cases. These findings document that small, autonomous systems are the most expensive among the NII. It would be beneficial to connect them to greater power grids. This is an actual priority of Greek energy policy, as verified by relevant official documents [21]. However, there are cases of NII which are far away from the mainland or groups of islands that have been connected to the IEG and this set obstacles to reducing energy production costs and increasing energy supply security. It is reminded that the cost variables are reduced to energy units $(€ / \mathrm{MWh})$ and so, the correlations presented in this Chapter are not self-evident.

Another important finding is that there is strong, negative correlation between electricity production costs and the energy produced by renewables. The energy production costs decrease when renewable energy production increases. As shown in Table 6, the correlations between electricity production costs and renewable energy production are significant at a confidence level of $99 \%$. The Spearman coefficient is also high; -0.900 in the case of variable cost and- 0.950 in the case of total cost. It should be noted that strong, negative correlation at a confidence level of $99 \%$ exists also between energy costs and installed capacity of renewable energy units. Hence, since diesel and mazut are relatively expensive fuels for electricity production, it is confirmed by the statistical findings that further use of renewable energy sources in the NII can lead to lower energy costs. However, as already discussed the current structure of autonomous, electrical systems sets technological restrictions to the further use of renewables. So, among else, energy storage is a possibility that should be examined thoroughly.

It is noted that Spearman coefficient is used for the correlations, because the 
distribution of the variables under study is not normal and the variables are not linearly related. Furthermore, it was possible to observe that there are monotonic relations between the variables, from the available statistical data. Hence, the use of Spearman correlation can provide useful results [22].

Table 5. Correlations between cost, thermal plants' energy production and installed capacity in the NII.

\begin{tabular}{|c|c|c|c|c|c|c|c|}
\hline & & & $\begin{array}{c}\text { Average annual } \\
\text { total cost }\end{array}$ & $\begin{array}{c}\text { Average annual } \\
\text { variable cost }\end{array}$ & $\begin{array}{c}\text { Served } \\
\text { population }\end{array}$ & $\begin{array}{c}\text { Thermal plants } \\
\text { production }\end{array}$ & $\begin{array}{l}\text { Installed } \\
\text { capacity }\end{array}$ \\
\hline & & Correlation Coefficient & 1.000 & $0.938^{\star *}$ & $-0.957^{\star *}$ & $-0.956^{\star *}$ & $-0.957^{\star *}$ \\
\hline & $\begin{array}{l}\text { Average annual } \\
\text { total cost }\end{array}$ & Sig. (2-tailed) & . & 0.000 & 0.000 & 0.000 & 0.000 \\
\hline & & $\mathrm{N}$ & 32 & 32 & 32 & 32 & 32 \\
\hline & & Correlation Coefficient & $0.938^{\star *}$ & 1.000 & $-0.890^{\star *}$ & $-0.890^{\star *}$ & $-0.889^{* *}$ \\
\hline & $\begin{array}{c}\text { Average annual } \\
\text { variable cost }\end{array}$ & Sig. (2-tailed) & 0.000 & . & 0.000 & 0.000 & 0.000 \\
\hline & & $\mathrm{N}$ & 32 & 32 & 32 & 32 & 32 \\
\hline & & Correlation Coefficient & $-0.957^{\star \star}$ & $-0.890^{* *}$ & 1.000 & $0.982^{\star *}$ & $0.980^{\star *}$ \\
\hline \multirow{7}{*}{$\begin{array}{l}\text { Spearman's } \\
\text { rho }\end{array}$} & & $\mathrm{N}$ & 32 & 32 & 32 & 32 & 32 \\
\hline & & Correlation Coefficient & $-0.956^{\star *}$ & $-0.890^{\star *}$ & $0.982^{\star *}$ & 1.000 & $0.997^{\star \star}$ \\
\hline & $\begin{array}{c}\text { Thermal plants } \\
\text { production }\end{array}$ & Sig. (2-tailed) & 0.000 & 0.000 & 0.000 & . & 0.000 \\
\hline & & $\mathrm{N}$ & 32 & 32 & 32 & 32 & 32 \\
\hline & & Correlation Coefficient & $-0.957^{\star \star}$ & $-0.889^{\star *}$ & $0.980^{* *}$ & $0.997^{\star *}$ & 1.000 \\
\hline & Installed capacity & Sig. (2-tailed) & 0.000 & 0.000 & 0.000 & 0.000 & . \\
\hline & & $\mathrm{N}$ & 32 & 32 & 32 & 32 & 32 \\
\hline
\end{tabular}

${ }^{*}$ Correlation is significant at the 0.01 level (2-tailed).

Table 6. Correlations between cost and renewable energy production in the NII.

\begin{tabular}{|c|c|c|c|c|c|}
\hline & & & $\begin{array}{l}\text { Average annual } \\
\text { total cost }\end{array}$ & $\begin{array}{c}\text { Average annual } \\
\text { variable cost }\end{array}$ & $\begin{array}{c}\text { Average renewable } \\
\text { production }\end{array}$ \\
\hline & & Correlation Coefficient & 1.000 & $0.938^{\star *}$ & $-0.950^{\star *}$ \\
\hline & $\begin{array}{l}\text { Average annual } \\
\text { total cost }\end{array}$ & Sig. (2-tailed) & . & 0.000 & 0.000 \\
\hline & & $\mathrm{N}$ & 32 & 32 & 32 \\
\hline & & Correlation Coefficient & $0.938^{\star *}$ & 1.000 & $-0.900^{\star *}$ \\
\hline \multirow[t]{5}{*}{$\begin{array}{l}\text { Spearman's } \\
\text { rho }\end{array}$} & $\begin{array}{l}\text { Average annual } \\
\text { variable cost }\end{array}$ & Sig. (2-tailed) & 0.000 & . & 0.000 \\
\hline & & $\mathrm{N}$ & 32 & 32 & 32 \\
\hline & & Correlation Coefficient & $-0.950^{\star *}$ & $-0.900^{* *}$ & 1.000 \\
\hline & $\begin{array}{c}\text { Average renewable } \\
\text { production }\end{array}$ & Sig. (2-tailed) & 0.000 & 0.000 & . \\
\hline & & $\mathrm{N}$ & 32 & 32 & 32 \\
\hline
\end{tabular}

${ }^{* *}$ Correlation is significant at the 0.01 level (2-tailed). 


\subsection{Investigation of Improvement Options for the Autonomous System of Astypalea}

Astypalea is an ideal and representative case study for investigating future perspectives of small, autonomous electrical systems in the Greek islands. It lies in the middle of the Aegean Sea (Figure 6), as reflected by the distance between the island and other greater islands, as well as the mainland:

- Astypalea-Kos: $55 \mathrm{~km}$

- Astypalea-Naxos: $90 \mathrm{~km}$

- Astypalea-Crete: $140 \mathrm{~km}$

- Astypalea-Rhodes: $170 \mathrm{~km}$

- Astypalea-Lavrio: $240 \mathrm{~km}$

- Astypalea-Athens: $280 \mathrm{~km}$

Hence, practically, the operation of an autonomous electrical system in Astypalea is compulsory, because its connection to other, greater electrical systems (or to the interconnected electricity grid of the mainland) is rather difficult.

The permanent population of the island, according to the last census, is 1334 inhabitants. The area of the island is $96.9 \mathrm{~km}^{2}$. Astypalea is a rather popular tourist destination, especially for alternative summer tourism and so, its population (and consequently the energy demand) rises during the summer. In Figure 7, a characteristic view of the main settlement of Astypalea (Chora) is shown.

The energy system of Astypalea is based on thermal plants that use diesel oil for electricity production. The type and the power of the islands' generators are shown in Table 7. In 2015, the fuel consumption for electrifying the island was $2,262,347$ lit of diesel oil; this is a high quantity of oil and its reduction will have positive results both from an economic and an environmental point of view. Moreover, there is an energy unit based on solar power in Astypalea that includes a photovoltaic array with peak power $320 \mathrm{~kW}$. The share of solar energy in the electricity consumption ranged between $8 \%$ and $9 \%$, in the period 2014-2017. As regards electricity consumption in Astypalea, for the period 2014-2017, the average values per month are shown in Figure 8. The maximum consumption (August) is almost 2.5 times higher than the minimum consumption (November). This is a typical situation for an island, whose main economic activity is summer tourism, as already discussed. The electrical load was possible to be retrieved by HEDNO, at an hourly base for the years 2014 and 2015. The hourly load is a prerequisite for conducting realistic simulations and optimizations. The peak load of the island was $2.25 \mathrm{MW}$ on $08 / 15 / 2015$, at 21.00. A view of the hourly load in Astypalea is given in Figure 9.

As far as the energy production costs are concerned, in Figure 10, the variable and the total cost are depicted, for the period 2014-2017, at a monthly basis. The average costs in Astypalea for the period 2014-2017 have as follows:

- Variable electricity production cost: 228.81€/MWh.

- Total electricity production cost: 379.27€/MWh.

So, Astypalea is ranked $11^{\text {th }}$ among the 32 autonomous systems regarding the variable cost of electricity production and $13^{\text {th }}$ regarding the total cost. It is rea- 
sonable that the reduction in the island's electrification cost is utterly necessary. For improving the current situation, by considering the findings of Section 3.4, the two main choices are: 1) connecting the island to the IEG and, 2) changing the current structure of Astypalea's system and increasing the use of renewable energy sources.

Table 7. Type, fuel and capacity of the electricity generators used in the electrical system of Astypalea [23].

\begin{tabular}{cccc}
\hline Type of generator & Fuel & Nominal Capacity $(\mathrm{kW})$ & Power Output $(\mathrm{kW})$ \\
\hline STORK ABR-216S & Diesel & 208 & 150 \\
STORK ABR-216S & Diesel & 208 & 150 \\
STORK ABR-216S & Diesel & 208 & 150 \\
STORK ABR-216S & Diesel & 208 & 150 \\
MITSUBISHI S16R-PTA & Diesel & 1275 & 1100 \\
MITSUBISHI S16R-PTA & Diesel & 1275 & 1100 \\
MITSUBISHI S16R-PTA & Diesel & 1275 & 1100 \\
\hline
\end{tabular}

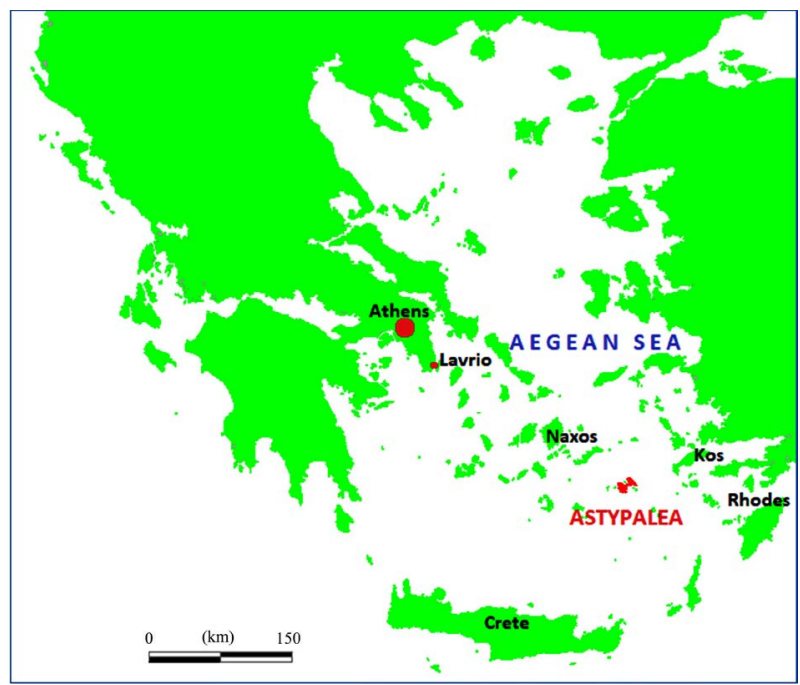

Figure 6. Map showing the position of Astypalea in Greece.

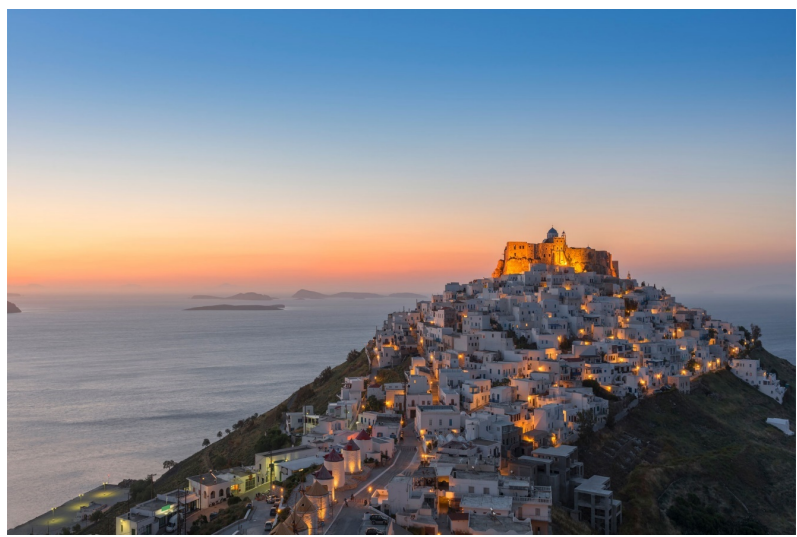

Figure 7. A view of the main settlement of Astypalea, known as Chora [24]. 


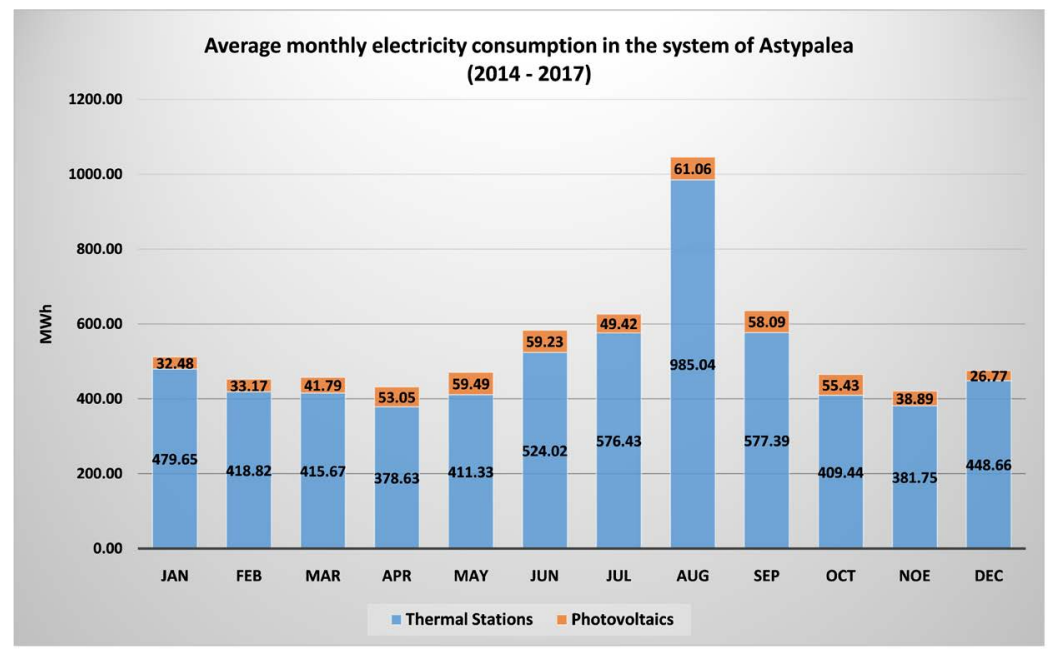

Figure 8. Average monthly electrical energy consumption in the energy system of Astypalea during the period 2014-2017.

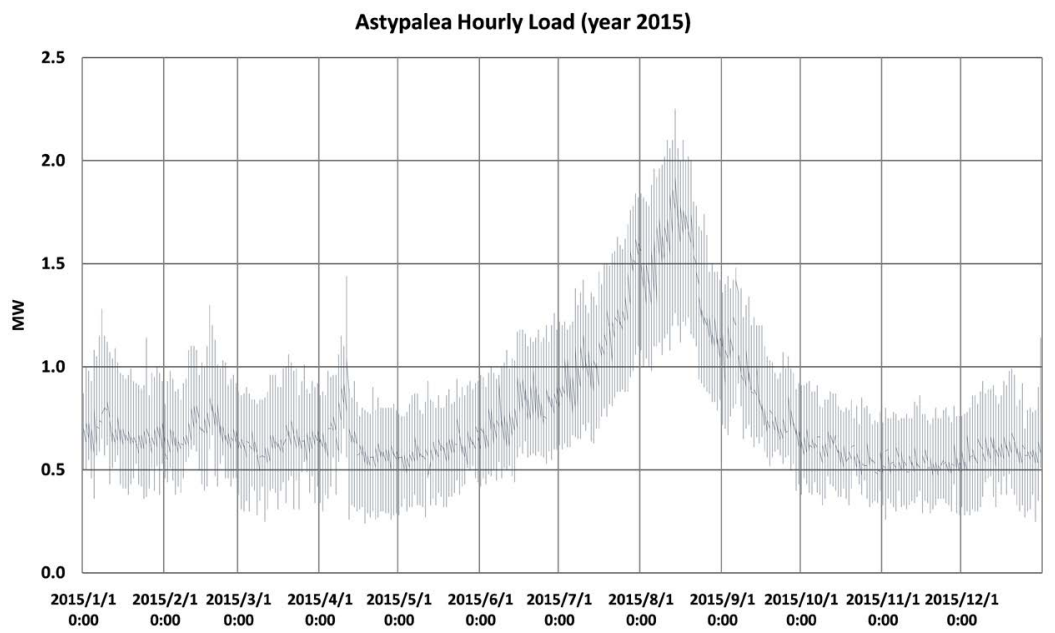

Figure 9. Hourly electricity load in the autonomous system of Astypalea in the year 2015.

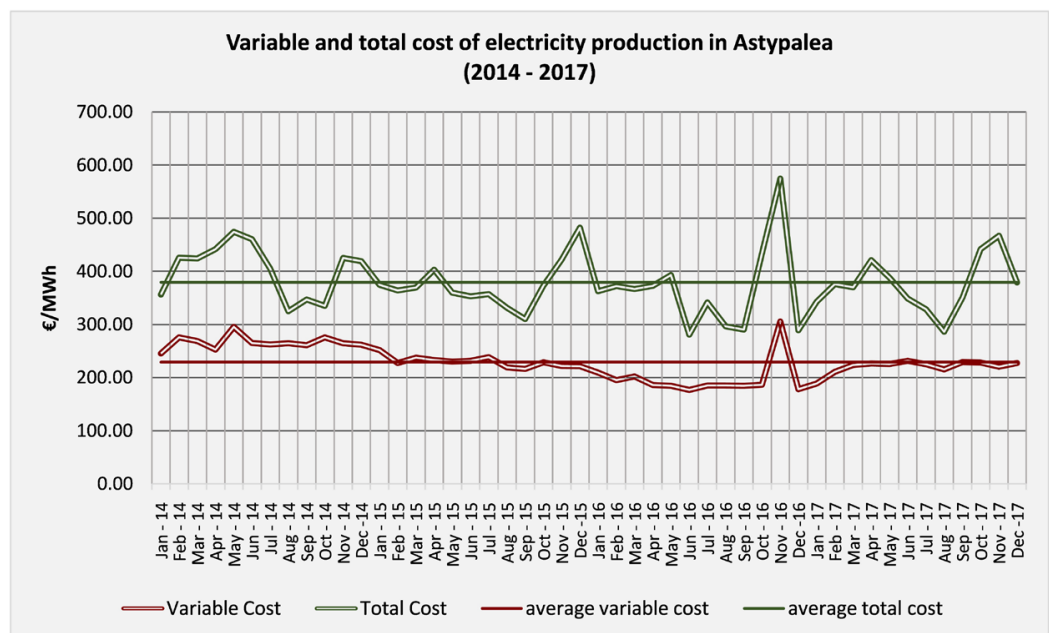

Figure 10. Variable and total electricity production cost per month, in the autonomous system of Astypalea, for the period 2014-2017. 


\subsubsection{Connecting the Autonomous System of Astypalea to the IEG}

As already mentioned, although the connection to the IEG is a strategic choice of the Greek Government, Astypalea is far away from the mainland and other bigger energy systems (Rhodes, Kos, Crete, Naxos). The costs for expanding energy grids with underwater cables are quite high. By combining data from relative sources [25] [26] [27], it is estimated that the necessary cost for expanding the grid towards autonomous island systems amounts to $1,000,000 € / \mathrm{km}$.

A simulation, including sensitivity analysis, was conducted with HOMER PRO x64, in order to investigate whether grid expansion towards Astypalea is a viable investment. It was proved that the expansion of the electricity grid cannot exceed $25 \mathrm{~km}$, for keeping the investment financially effective. As already discussed, Astypalea is far away both form the mainland and other, bigger islands; minimum distance $55 \mathrm{~km}$. Therefore, it is not feasible to expand the electricity grid just for electrifying this island.

\subsubsection{Changing the Current Structure of Astypalea's Energy System}

By using HOMER PRO x64, different scenarios of re-structuring the autonomous electrical system of Astypalea are analyzed. The main aim of energy optimization in the island is to reduce energy production costs in a sustainable way. Therefore, further use of renewable energy sources is necessary. The scenarios investigated are the following:

- Scenario A: Further use of renewable energy without the addition of storage

- A1: Photovoltaics and small hydropower station.

- A2: Photovoltaics, wind generators and small hydropower station.

- Scenario B: Further use of renewable energy with the addition of energy storage systems (Li-Ion) batteries

- B1: Photovoltaics and battery array.

- B2: Photovoltaics, wind generators and battery array.

- B3: Photovoltaics, wind generators, small hydropower station and battery array.

The cases B1, B2 and B3 have been simulated with different assumptions regarding the costs of the batteries. So, there are-additionally-three cases, namely B1a, B2a, B3a which have the same structure as the abovementioned (B1, B2, B3), but are simulated with $40 \%$ lower costs of batteries, following the relevant tendency in the energy market. The assumptions regarding investment and operation and maintenance costs of the various systems are presented in Table S3 of the Appendix.

Regarding energy potential, for solar and wind energy potential the data from the libraries of HOMER were used. As far as hydropower is concerned, the cause for exploiting this source of energy in an island with low rates of precipitation is the fact that there is a water reservoir near the village of Livadi. This reservoir is used for providing potable water. So, a small turbine can be used, in order to utilize the available hydraulic head when transferring water from the reservoir to consumers. According to Daniil (2018) [23], the available hydraulic head is $32 \mathrm{~m}$ 
and, by considering the volume of the reservoir and the precipitation in the island, a small turbine with $80 \mathrm{~kW}_{\mathrm{el}}$ capacity can be installed. The data retrieved by HOMER library regarding solar and wind potential, as well as the assumptions regarding hydropower in Astypalea are summarized in Table S4 in the Appendix.

The simulations carried out by using HOMER PRO x64 led to the optimal solutions shown in Table 8, while in Table 9 the investment costs, the unit energy cost, the annual energy cost, the annual diesel oil consumption and the renewable energy share of each scenario are presented. It is notable that in order to reduce the installed capacity of diesel generators, storage systems are necessary for avoiding power shortages. Even if the optimization results show that the renewable energy capacity and share can increase significantly without using storage systems, it is risky to operate an autonomous small system with low inertia under such conditions. The use of batteries can ensure power supply, with simultaneous increase in renewable energy use. Under favorable conditions regarding batteries' cost, the renewable energy share in Astypalea can exceed $45 \%$ and the unit energy cost can decrease by $42 \%$, in comparison with the current situation. It should also be highlighted that the possibility to utilize hydropower, because of the existing water dam in the island, is particularly important, because of the generally higher load factors of hydro-stations, compared to PVs and wind generators. The operation of a small hydro-plan increases energy supply security and has positive impact on the system's stability.

The investment costs vary between 786,000 and 2,426,000, depending on the renewable and storage capacity installed. Such amounts are much more competitive compared to the electrification of Astypalea through submarine cables, as shown in Section 3.5.1. Of course, the present results are a first attempt to optimize Astypalea's system. Apart from a feasibility study, the further use of renewables in the island demand a precise cost-benefit analysis, based on extensive data from the energy market.

Table 8. Structure of Astypalea's energy system in the current situation and under the various future scenarios.

\begin{tabular}{cccccc}
\hline Scenario & $\begin{array}{c}\text { Number } \\
\text { of Diesel } \\
\text { Generators/ } \\
\text { Capacity }(\mathrm{kW})\end{array}$ & $\begin{array}{c}\text { Photovoltaics } \\
(\mathrm{kW})\end{array}$ & $\begin{array}{c}\text { Wind } \\
\text { Generators } \\
(\mathrm{kW})\end{array}$ & $\begin{array}{c}\text { Hydropower } \\
(\mathrm{kW})\end{array}$ & $\begin{array}{c}\text { Li-Ion } \\
\text { Batteries } \\
(\mathrm{kWh})\end{array}$ \\
\hline Current situation & $7 / 3900$ & 320 & - & - & - \\
A1 & $7 / 3900$ & 1072 & - & 80 & - \\
A2 & $7 / 3900$ & 550 & 450 & 80 & - \\
B1 & $7 / 3900$ & 1497 & - & - & 500 \\
B2 & $5 / 1700$ & 835 & 700 & - & 500 \\
B3 & $5 / 1700$ & 767 & 650 & 80 & 400 \\
B1a & $7 / 3900$ & 1135 & - & - & 700 \\
B2a & $5 / 1700$ & 880 & 700 & - & 600 \\
B3a & $5 / 1700$ & 723 & 675 & 80 & 500 \\
\hline
\end{tabular}


Table 9. Investment costs, unit energy costs, annual energy costs, annual diesel oil consumption and renewable energy share for the current situation of Astypalea's energy system and under the various future scenarios.

\begin{tabular}{cccccc}
\hline Scenario & Investment cost $(€)$ & $\begin{array}{c}\text { Unit energy cost } \\
(€ / \text { MWh) }\end{array}$ & $\begin{array}{c}\text { Annual operating } \\
\text { cost }(€)\end{array}$ & $\begin{array}{c}\text { Annual diesel } \\
\text { oil consumption (lit) }\end{array}$ & $\begin{array}{c}\text { Renewable energy } \\
\text { share (\%) }\end{array}$ \\
\hline Current situation & - & $230^{*}$ & $1,428,851^{\star}$ & $2,262,347^{*}$ & $8.54^{*}$ \\
A1 & 786,000 & 151 & 865,968 & $1,388,401$ & 25.4 \\
A2 & $1,896,000$ & 144 & 735,066 & $1,119,778$ & 40.6 \\
B1 & $1,376,000$ & 156 & 850,623 & $1,337,461$ & 26.2 \\
B2 & $2,546,000$ & 143 & 680,213 & 995,450 & 45.0 \\
B3 & $2,406,000$ & 136 & 650,781 & 952,375 & 47.6 \\
B1a & $1,266,000$ & 152 & 835,679 & $1,311,072$ & 27.1 \\
B2a & $2,426,000$ & 140 & 669,158 & 977,368 & 43.7 \\
B3a & $2,306,000$ & 133 & 639,273 & 933,276 & 48.2 \\
\hline
\end{tabular}

${ }^{\star}$ Data referring to the year 2015 .

\section{Conclusions}

The research presented in this paper highlighted: 1) the characteristics and problems related to the electrification of Greek islands not connected to the IEG, and 2) provided evidence for planning a better energy future in small, remote islands. The most important conclusions that also produce policy implications regarding sustainable development are summarized below:

- The NII of Greece demand high energy costs for their electrification (in average 2.5 times higher expenses compared to the grid of the mainland), while the present structure of the autonomous electrical systems leads to the insecurity of energy supply and does not allow the exploitation of the plentiful solar and wind energy potential of the islands.

- The use of mazut and diesel for producing more than $80 \%$ of the electrical energy needed in the NII does not only have high financial and environmental cost, but it also maintains the country's high energy dependency, mainly arising from oil imports; the energy dependency of Greece was $72.5 \%$ in 2016, while the EU average was 54\% during the same period [28].

- The priority of Greece's energy planning for the future of NII with big energy loads (Crete, Rhodes, Mykonos, Paros) is the expansion of the IEG. This is a reasonable choice for cases with high energy demand and high capacities of installed RES, since the share of renewables in the country will, in general, increase in this way.

- In cases of remote islands with low energy loads, it seems that the improvement of the local autonomous systems is a better choice than the interconnection with the main electricity grid. For the case of Astypalea-peak load 2.25 MW and average load 0.72 MW-the investment for expanding the grid with submarine cables is not viable for expansion greater than $25 \mathrm{~km}$.

- The case of Astypalea provides strong evidence regarding the possibility to 
utilize local RES together with the use of storage systems, in order to improve current situation in small NII. The perspectives of the local autonomous system for sustainable improvement are promising: more than $45 \%$ renewable share $(8.5 \%$ currently), $42 \%$ reduction in the unit energy production cost, and $58 \%$ reduction in diesel oil consumption with investment costs up to 2.4 million euros.

Apparently, the work presented in this paper presents some limitations. The main amongst them are: 1) the focus on one island, namely Astypalea, and 2) the fact that thermal energy loads are not included in the energy simulations. These limitations can be addressed by the following steps of future work:

- Collection of hourly electrical load data from all the NII of Greece and conduction of simulations like the ones presented for the case of Astypalea.

- Highlight common characteristics regarding loads, consumption and future structures of energy systems among groups of NII.

- Introduce thermal energy loads in the energy simulation, in order to gain a broad view of the energy future of small, remote islands.

In conclusion, the autonomous electrical systems of Greek islands, although currently are characterized by very high energy costs, are challenging places for implementing sustainable solutions. The NII, particularly the remote ones, are an ideal case for utilizing renewables in favor of local societies, at the basis of decentralized applications. The current model of RES development has been based on projects with great installed capacities that provide energy to the IEG, at significantly high prices. In many cases the sustainability of this RES model has been controverted. On the contrary, decentralized RES exploitation in remote islands is a mild, viable way of utilizing green energy. Government policies should more actively support this kind of energy future for NII. The present paper documents this statement, as well as pilot projects like TILOS, aiming at integrating batteries in autonomous systems [29].

\section{Conflicts of Interest}

The author declares no conflicts of interest regarding the publication of this paper.

\section{References}

[1] Hellenic Republic (2008) Constitution of Greece. (In Greek) http://www.et.gr/images/stories/eidika_themata/a_120_2008.pdf

[2] Katsoulakos, N. and Kaliampakos, D. (2014) What Is the Impact of Altitude on Energy Demand? A Step towards Developing Specialized Energy Policy for Mountainous Areas. Energy Policy, 71, 130-138. https://doi.org/10.1016/j.enpol.2014.04.003

[3] Katsoulakos, N. and Kaliampakos, D. (2016) Mountainous Areas and Decentralized Energy Planning: Insights from Greece. Energy Policy, 91, 174-188. https://doi.org/10.1016/j.enpol.2016.01.007

[4] Katsoulakos, N. and Kaliampakos, D. (2018) The Energy Identity of Mountainous 
Areas: The Example of Greece. Journal of Mountain Science, 15, 1429-1445. https://doi.org/10.1007/s11629-018-4830-8

[5] HSA (2018) Greece in Numbers. Hellenic Statistical Authority, Piraeus.

[6] Chatziargyriou, N. (2016) Management of Non-Interconnected Islands (NII) with High Share of Renewable Energy. (In Greek) https://www.deddie.gr/Documents2/PAROYSIASEIS\%202016/Presentation\%20Vio simes.pdf

[7] Prodromidis, G.N. and Coutelieris, F.A. (2011) A Comparative Feasibility Study of Stand-Alone and Grid Connected RES-Based Systems in Several Greek Islands. Renewable Energy, 36, 1957-1963. https://doi.org/10.1016/j.renene.2010.12.021

[8] Katsaprakakis, D. and Voumvoulakis, M. (2018) A Hybrid Power Plant towards $100 \%$ Energy Autonomy for the Island of Sifnos, Greece. Perspectives Created from Energy Cooperatives. Energy, 161, 680-698. https://doi.org/10.1016/j.energy.2018.07.198

[9] Zafeiratou, E. and Spataru, C. (2018) Sustainable Island Power System-Scenario Analysis for Crete under the Energy Trilemma Index. Sustainable Cities and Society, 41, 378-391. https://doi.org/10.1016/j.scs.2018.05.054

[10] Walker, M. (2016) HOMER Optimizer, a Faster Path to Finding Least-Cost Microgrid Options.

http://microgridnews.com/homer-optimizer-a-faster-path-to-finding-least-cost-mic rogrid-options

[11] HSA (2012) Hellenic Statistical Authority. Demographic Characteristics 2011. (In Greek) http://www.statistics.gr/el/statistics/-/publication/SAM03

[12] HDNO (2018) Informative Bulletin Regarding Electricity Production in the Non-Interconnected Islands for April 2018. Hellenic Electricity Distribution Network Operator, Athens. (In Greek)

[13] RAE (2014) Regulatory Authority for Energy. Non-Interconnected Islands. (In Greek) http://www.rae.gr/site/categories_new/electricity/market/mdn.csp

[14] OEM (2018) Monthly Bulletin of Daily Energy Planning. Operator of Electricity Market, Athens. (In Greek)

[15] IPTO (2018) Independent Power Transmission Operator. (In Greek) http://www.admie.gr/leitoyrgia-dedomena/leitoyrgia-agoras-ilektrikis-energeias/pro thesmiaki-agora/dedomena-eisodoy/problepsi-fortioy

[16] Government Gazette (2012) Law 4027/2012. Hellenic Republic, Athens. (In Greek)

[17] HDNO (2015) Methodology for Calculating Collaterals for Load Representatives during the Transitional Period of the Implementation of the Non-Interconnected Islands Regulation. Hellenic Electricity Distribution Network Operator, Athens. (In Greek)

[18] Kounalakis, M. and Kollias, F. (2018) Energy Press, Portal for Energy. https://energypress.gr/news/mystirio-me-ta-ekatontades-ekatommyria-eyro-gia-tayko-tis-dei

[19] RAE (2018) Regulation for Operating the Electrical Systems of Non-Interconnected Islands (NII Regulation). 2nd Edition, Regulatory Authority for Energy, Athens. (In Greek)

[20] Energypress (2017) Energypress, Portal for Energy. (In Greek) https://energypress.gr/news/egkrithike-i-egkatastasi-prosthetis-ishyos-sta-nisia-giakalokairi-i-rae-vazei-telos-sti

[21] Government Gazette (2018) Approval of the Ten-Year Development Plan of the 
National System of Electrical Energy Transmission. Hellenic Republic, Athens. (In Greek)

[22] Zafeiropoulos, K. (2008) Open Digital Classes, Statistical Analysis Using a Computer. University of Macedonia, Thessaloniki. http://opencourses.uom.gr/assets/site/public/127/70-Statistikh-Analysi-08-Zafeirop oulos.pdf

[23] Daniil, V. (2018) Investigation of Renewable Energy Use in the Non-Interconnected Island of Astypalea. Diploma Thesis, National Technical University of Athens, Athens. (In Greek)

[24] Aegean Sea Villas (2017) Aegean Sea Villas-Luxury Seaside Detached Homes. (In Greek) https://aegeanseavillas.com/el/astypalaia-gr/astypalaia-gr

[25] Papadopoulos, M., Papathanasiou, S. and Karamanou, E. (2008) Update of the Strategic Study Regarding the Connection of Islands to the Interconnected Electricity Grid. Research Project, Regulatory Authority for Energy, Athens. (In Greek)

[26] RAE (2011) Development Study of Crete's Electric System. Technical Report, Executive Summary, Regulatory Authority for Energy, Athens. (In Greek)

[27] Fragkoulis, E. (2016) Electrical Connection of Crete with the Mainland System. Postgraduate Thesis, University of Pireus, Pireus. (In Greek)

[28] Energia.gr (2018) National Strategy and Petroleum. (In Greek) https://www.energia.gr/article/147553/ethnikh-strathgikh-kai-petrelaio

[29] Tilos (2018) Technology Innovation for the Local Scale. Optimum Integration of Battery Energy Storage. Website of Research Project.

https://www.tiloshorizon.eu 


\section{Appendix}

Table S1. Average monthly energy consumption in the electrical systems of the non-interconnected islands in MWh.

\begin{tabular}{|c|c|c|c|c|c|c|c|c|c|c|c|c|c|c|c|}
\hline & & $\begin{array}{c}\text { Agios } \\
\text { Efstratios }\end{array}$ & Agathonissi & iAmorgos & Anafi & Antikyhtira & Arkioi & Astypalea & Gavdos & Dosnoussa & Erikoussa & Thira & Ikaria & Karpathos & Crete \\
\hline \multirow{2}{*}{ JAN } & Thermal & 0.00 & 0.00 & 23.26 & 0.00 & 0.00 & 0.00 & 31.87 & 0.00 & 0.00 & 0.00 & 56.01 & 234.14 & 299.68 & $48,823.23$ \\
\hline & RES & 101.43 & 68.44 & 678.53 & 84.18 & 21.96 & 19.99 & 492.61 & 37.68 & 48.46 & 48.78 & 8127.05 & 2244.55 & 2419.13 & $190,154.40$ \\
\hline \multirow{2}{*}{ FEB } & Thermal & 0.00 & 0.00 & 26.27 & 0.00 & 0.00 & 0.00 & 34.43 & 0.00 & 0.00 & 0.00 & 57.86 & 234.36 & 304.29 & $45,028.67$ \\
\hline & RES & 86.81 & 57.00 & 603.09 & 76.80 & 20.14 & 19.15 & 421.73 & 35.11 & 44.36 & 55.70 & 7479.09 & 1858.88 & 1933.57 & $159,175.29$ \\
\hline \multirow{2}{*}{ MAR } & Thermal & 0.00 & 0.00 & 39.33 & 0.00 & 0.00 & 0.00 & 44.14 & 0.00 & 0.00 & 0.00 & 77.30 & 237.15 & 388.73 & $51,792.66$ \\
\hline & RES & 91.10 & 60.16 & 619.25 & 76.19 & 20.68 & 18.09 & 414.17 & 38.01 & 45.69 & 51.74 & 8686.64 & 1924.53 & 1928.12 & $157,425.51$ \\
\hline \multirow{2}{*}{ APR } & Thermal & 0.00 & 0.00 & 45.96 & 0.00 & 0.00 & 0.00 & 54.25 & 0.00 & 0.00 & 0.00 & 95.39 & 234.32 & 352.30 & $46,113.36$ \\
\hline & RES & 78.24 & 51.21 & 628.37 & 71.51 & 19.44 & 20.03 & 381.90 & 33.42 & 43.77 & 55.56 & $10,704.09$ & 1686.99 & 1798.37 & $155,798.54$ \\
\hline MAY & RES & 77.82 & 52.64 & 654.66 & 82.48 & 19.87 & 28.87 & 411.11 & 35.97 & 54.45 & 56.25 & $14,135.82$ & 1627.99 & 2411.24 & $183,165.08$ \\
\hline \multirow[b]{2}{*}{ JUN } & Thermal & 0.00 & 0.00 & 51.34 & 0.00 & 0.00 & 0.00 & 60.26 & 0.00 & 0.00 & 0.00 & 109.09 & 232.85 & 434.49 & $54,936.32$ \\
\hline & RES & 86.19 & 55.27 & 833.12 & 114.00 & 20.23 & 36.64 & 533.90 & 42.87 & 86.87 & 66.44 & $17,273.43$ & 1890.34 & 3349.81 & $216,448.59$ \\
\hline \multirow{2}{*}{ JUL } & Thermal & 0.00 & 0.00 & 56.13 & 0.00 & 0.00 & 0.00 & 66.02 & 0.00 & 0.00 & 0.00 & 113.06 & 347.09 & 535.56 & $83,101.92$ \\
\hline & RES & 111.35 & 74.77 & 1217.40 & 171.85 & 24.10 & 47.19 & 798.20 & 51.66 & 131.32 & 107.18 & $21,022.93$ & 2520.74 & 4349.55 & $241,549.41$ \\
\hline \multirow{2}{*}{ AUG } & Thermal & 0.00 & 0.00 & 49.14 & 0.00 & 0.00 & 0.00 & 61.25 & 0.00 & 0.00 & 0.00 & 105.93 & 318.24 & 475.67 & $77,410.77$ \\
\hline & RES & 130.24 & 74.85 & 1449.93 & 229.84 & 28.19 & 56.88 & 986.81 & 55.46 & 154.16 & 134.01 & $22,508.50$ & 3196.82 & 4998.12 & $256,233.51$ \\
\hline \multirow[b]{2}{*}{ SEP } & Thermal & 0.00 & 0.00 & 45.93 & 0.00 & 0.00 & 0.00 & 57.67 & 0.00 & 0.00 & 0.00 & 96.26 & 254.69 & 395.79 & $54,037.38$ \\
\hline & RES & 84.10 & 54.71 & 955.92 & 128.52 & 23.60 & 39.99 & 580.78 & 45.98 & 95.79 & 71.33 & $18,537.99$ & 2130.79 & 3686.15 & $228,557.63$ \\
\hline \multirow[t]{2}{*}{ OCT } & & & & & & & & & & & & & & & \\
\hline & RES & 78.26 & 47.69 & 639.66 & 78.17 & 19.94 & 27.76 & 408.75 & 37.32 & 52.33 & 54.40 & $13,501.54$ & 1723.73 & 2120.14 & $181,347.86$ \\
\hline \multirow[b]{2}{*}{ NOV } & Thermal & 0.00 & 0.00 & 31.17 & 0.00 & 0.00 & 0.00 & 38.28 & 0.00 & 0.00 & 0.00 & 66.40 & 237.03 & 300.00 & $47,211.07$ \\
\hline & RES & 84.32 & 48.64 & 593.91 & 72.43 & 19.07 & 19.07 & 385.06 & 33.74 & 43.01 & 49.77 & 7941.67 & 1848.86 & 1773.05 & $149,922.77$ \\
\hline \multirow[b]{2}{*}{$\mathrm{DEC}$} & Thermal & 0.00 & 0.00 & 24.16 & 0.00 & 0.00 & 0.00 & 27.71 & 0.00 & 0.00 & 0.00 & 53.64 & 266.65 & 316.25 & $53,480.38$ \\
\hline & RES & 95.74 & 60.78 & 650.85 & 78.03 & 21.27 & 18.86 & 446.12 & 36.75 & 46.03 & 49.16 & 8091.01 & 2138.77 & 2150.86 & $180,133.07$ \\
\hline
\end{tabular}

\begin{tabular}{|c|c|c|c|c|c|c|c|c|c|c|c|c|c|c|c|}
\hline & & Kythnos & $\begin{array}{c}\text { Kos- } \\
\text { Kalymnos }\end{array}$ & Lesvos & Lemnos & Megisti & Milos & Mykonos & Othoni & Paros & Patmos & Rhodes & Samos & Serifos & Sifnos \\
\hline \multirow{2}{*}{ JAN } & Thermal & 21.20 & 3698.20 & 3796.77 & 534.86 & 0.00 & 606.91 & 360.16 & 0.00 & 2951.49 & 199.06 & 8570.98 & 2004.49 & 11.52 & 28.47 \\
\hline & RES & 645.40 & $21,259.13$ & $25,480.72$ & 4835.49 & 251.16 & 3154.17 & 6195.70 & 46.12 & $11,808.04$ & 1262.40 & $46,689.46$ & $10,425.91$ & 597.42 & 1166.16 \\
\hline FEB & Thermal & 22.66 & 3184.70 & 4199.54 & 572.55 & 0.00 & 633.17 & 344.13 & 0.00 & 2669.22 & 162.21 & 7496.10 & 1892.15 & 11.66 & 32.02 \\
\hline \multirow{2}{*}{ MAR } & Thermal & 28.35 & 3325.68 & 4199.28 & 617.63 & 0.00 & 696.64 & 392.56 & 0.00 & 3303.06 & 157.89 & 8566.97 & 1954.47 & 16.36 & 44.01 \\
\hline & RES & 584.67 & $16,801.38$ & $19,952.70$ & 4163.62 & 214.88 & 2957.55 & 6307.41 & 41.04 & $10,315.43$ & 1071.94 & $35,744.38$ & 8918.58 & 545.32 & 1038.38 \\
\hline \multirow{2}{*}{ APR } & Thermal & 38.18 & 3257.96 & 3816.95 & 552.40 & 0.00 & 484.64 & 333.54 & 0.00 & 2679.51 & 126.94 & 8296.98 & 1616.26 & 18.00 & 53.06 \\
\hline & RES & 1276.46 & $16,715.28$ & $16,896.26$ & 3624.04 & 199.41 & 5924.85 & 7851.31 & 44.23 & $11,184.83$ & 1074.06 & $36,875.27$ & 7362.95 & 1414.29 & 2235.96 \\
\hline
\end{tabular}




\section{Continued}

\begin{tabular}{|c|c|c|c|c|c|c|c|c|c|c|c|c|c|c|c|}
\hline \multirow{2}{*}{ MAY } & Thermal & 37.95 & 3747.12 & 3951.06 & 611.09 & 0.00 & 575.83 & 329.21 & 0.00 & 2728.85 & 125.57 & 9995.05 & 1895.75 & 20.26 & 61.41 \\
\hline & RES & 559.38 & $26,476.75$ & $16,734.59$ & 3524.21 & 215.34 & 3290.20 & $11,385.73$ & 45.04 & $12,847.41$ & 1121.45 & $54,268.93$ & 7870.36 & 530.10 & 1232.66 \\
\hline \multirow{2}{*}{ JUN } & Thermal & 40.60 & 4402.01 & 3535.01 & 570.35 & 0.00 & 545.42 & 360.29 & 0.00 & 3049.14 & 189.73 & $13,577.41$ & 2336.83 & 23.36 & 62.85 \\
\hline & RES & 700.47 & $34,907.44$ & $19,608.96$ & 4221.53 & 279.11 & 3782.49 & $14,862.04$ & 54.40 & $17,800.85$ & 1363.85 & $69,761.05$ & 9212.87 & 731.05 & 1688.14 \\
\hline \multirow{2}{*}{ JUL } & Thermal & 41.64 & 5784.85 & 5033.14 & 815.86 & 0.00 & 1034.85 & 513.70 & 0.00 & 5036.93 & 381.52 & $16,685.49$ & 3581.75 & 25.97 & 67.63 \\
\hline & RES & 1069.45 & $43,159.25$ & $23,193.75$ & 5380.37 & 430.96 & 4484.24 & $19,103.93$ & 77.69 & $23,794.45$ & 1699.23 & $90,348.54$ & $10,560.23$ & 1124.19 & 2441.26 \\
\hline \multirow{2}{*}{ AUG } & Thermal & 39.85 & 5001.38 & 4799.17 & 943.15 & 0.00 & 946.27 & 508.37 & 0.00 & 4880.00 & 335.01 & $15,994.22$ & 3563.68 & 24.00 & 64.44 \\
\hline & RES & 1380.61 & $47,360.10$ & $25,553.53$ & 5940.79 & 478.29 & 4916.28 & $20,956.38$ & 103.66 & $27,955.77$ & 2158.92 & $97,148.20$ & $12,114.94$ & 1407.29 & 2884.18 \\
\hline \multirow{2}{*}{ SEP } & Thermal & 40.64 & 4252.53 & 3762.27 & 708.66 & 0.00 & 565.80 & 341.14 & 0.00 & 3308.94 & 209.71 & $13,260.05$ & 2480.87 & 20.83 & 56.26 \\
\hline & RES & 739.56 & $36,598.14$ & $19,384.48$ & 4201.32 & 365.91 & 3844.59 & $16,525.09$ & 54.25 & $18,138.47$ & 1441.40 & $77,250.53$ & 9657.49 & 736.86 & 1755.40 \\
\hline \multirow{2}{*}{ OCT } & Thermal & 34.21 & 4373.31 & 3612.57 & 607.83 & 0.00 & 688.18 & 411.57 & 0.00 & 3471.26 & 172.41 & $11,003.16$ & 2346.28 & 17.91 & 51.21 \\
\hline & RES & 519.63 & $24,780.65$ & $16,770.67$ & 3635.77 & 241.87 & 2703.10 & 9079.16 & 41.58 & $10,795.34$ & 1006.96 & $54,775.86$ & 7222.32 & 457.45 & 1046.06 \\
\hline \multirow{2}{*}{ NOV } & Thermal & 25.30 & 2896.86 & 3046.98 & 481.27 & 0.00 & 579.08 & 312.82 & 0.00 & 2833.77 & 124.70 & 6415.24 & 1907.26 & 14.65 & 38.14 \\
\hline & RES & 506.43 & $15,606.44$ & $19,487.31$ & 3965.84 & 201.72 & 2831.93 & 5578.17 & 38.65 & 9901.65 & 947.88 & $33,335.75$ & 8014.29 & 446.47 & 963.68 \\
\hline \multirow{2}{*}{ DEC } & Thermal & 19.80 & 3846.98 & 4085.12 & 581.95 & 0.00 & 622.54 & 375.76 & 0.00 & 3241.56 & 197.68 & 7914.10 & 2371.81 & 11.90 & 30.61 \\
\hline & RES & 599.34 & $19,228.52$ & $23,794.03$ & 4550.83 & 244.03 & 2848.85 & 5835.81 & 40.03 & $11,080.45$ & 1142.23 & $41,231.24$ & 9693.37 & 514.71 & 1112.25 \\
\hline & & & & \multicolumn{3}{|c|}{ Skyros } & \multicolumn{3}{|c|}{ Symi } & \multicolumn{3}{|c|}{ Syros } & \multicolumn{3}{|c|}{ Chios } \\
\hline \multirow{2}{*}{\multicolumn{2}{|c|}{ JAN }} & \multicolumn{2}{|c|}{ Thermal } & \multicolumn{3}{|c|}{19.29} & \multicolumn{3}{|c|}{10.65} & \multicolumn{3}{|c|}{504.06} & \multicolumn{3}{|c|}{2142.63} \\
\hline & & \multicolumn{2}{|c|}{ RES } & \multicolumn{3}{|c|}{1304.54} & \multicolumn{3}{|c|}{1152.83} & & & 364.84 & & $18,530$. & \\
\hline & & & rmal & & 26.07 & & & 15. & & & & 11.30 & & 2205.4 & \\
\hline & & & ES & & 1197.90 & & & 962. & & & & 19.94 & & 15,049 . & \\
\hline & & & rmal & & 37.45 & & & 21.8 & & & & 20.71 & & 2338.1 & \\
\hline & & & ES & & 1223.11 & & & 937. & & & & 25.67 & & 14,918 . & \\
\hline & & & rmal & & 51.82 & & & 28.7 & & & & 08.42 & & 2076.5 & \\
\hline & & & ES & & 1049.31 & & & 897. & & & & 335.57 & & $11,790$. & \\
\hline & & & ermal & & 59.33 & & & 30. & & & & 72.41 & & 2301.0 & \\
\hline & & & ES & & 1021.19 & & & 993. & & & & 260.66 & & 11,545 . & \\
\hline & & & ermal & & 54.24 & & & 31.2 & & & & 36.61 & & 2133.5 & \\
\hline & & & ES & & 1220.58 & & & 1261 & & & & 195.06 & & 13,639 . & \\
\hline & & & rmal & & 59.98 & & & 31.7 & & & & 60.41 & & 3104.6 & \\
\hline & & & ES & & 1723.26 & & & 1634 & & & & 733.79 & & 16,577 & \\
\hline & & & rmal & & 59.95 & & & 29.2 & & & & 52.97 & & 2844.7 & \\
\hline & & & ES & & 2028.79 & & & 2015 & & & & 325.53 & & $19,195$. & \\
\hline & & & rrmal & & 46.79 & & & 24. & & & & 93.92 & & 2169.0 & \\
\hline & & & ES & & 1198.98 & & & 1429 & & & & 257.50 & & 13,755 . & \\
\hline & & & ermal & & 37.06 & & & 21.2 & & & & 91.24 & & 2269.7 & \\
\hline & & & ES & & 993.04 & & & 1081 & & & & 225.10 & & 11,966 & \\
\hline & & & ermal & & 26.85 & & & 14.8 & & & & 00.81 & & 2062.4 & \\
\hline & & & ES & & 1065.20 & & & 883. & & & & 391.76 & & 13,842 . & \\
\hline & & & rmal & & 21.78 & & & 11.2 & & & & 87.92 & & 2395.3 & \\
\hline & & & ES & & 1228.43 & & & 1029 & & & & 612.93 & & $17,481$. & \\
\hline
\end{tabular}


Table S2. Average monthly variable and total electricity production costs in the electrical systems of the non-interconnected islands in $€ / M W h$.

\begin{tabular}{|c|c|c|c|c|c|c|c|c|c|c|c|c|c|c|c|}
\hline & & $\begin{array}{c}\text { Agios } \\
\text { Efstratios }\end{array}$ & Agathoniss & Amorgos & Anafi & Antikyhtira & Arkioi & Astypalea & Gavdos & Dosnoussa & Erikoussa & Thira & Ikaria & Karpathos & Crete \\
\hline \multirow{2}{*}{ JAN } & Variable & 267.09 & 326.94 & 230.04 & 266.64 & 391.27 & 398.90 & 223.84 & 278.28 & 302.90 & 319.97 & 123.40 & 216.30 & 126.22 & 138.66 \\
\hline & Total & 450.81 & 593.11 & 389.87 & 567.34 & 1224.55 & 921.28 & 358.92 & 566.45 & 1073.58 & 835.24 & 211.23 & 359.40 & 247.92 & 180.50 \\
\hline \multirow{2}{*}{ FEB } & Variable & 271.38 & 316.08 & 224.47 & 294.46 & 386.13 & 401.14 & 227.29 & 277.68 & 318.19 & 321.94 & 133.26 & 195.67 & 130.34 & 142.87 \\
\hline & Total & 433.95 & 718.97 & 386.80 & 1027.30 & 1280.73 & 1134.27 & 384.30 & 649.66 & 1055.26 & 765.57 & 262.47 & 351.10 & 281.53 & 194.12 \\
\hline \multirow{2}{*}{ MAR } & Variable & 275.29 & 329.88 & 226.76 & 258.33 & 391.77 & 609.87 & 233.08 & 282.41 & 315.94 & 324.74 & 139.95 & 210.24 & 117.47 & 139.65 \\
\hline & Total & 732.81 & 637.34 & 395.14 & 523.08 & 1216.64 & 1537.58 & 382.47 & 563.49 & 1281.23 & 848.92 & 229.95 & 369.72 & 258.26 & 190.94 \\
\hline \multirow{2}{*}{ APR } & Variable & 270.32 & 726.25 & 226.41 & 273.64 & 371.38 & 368.24 & 224.64 & 297.69 & 320.58 & 337.68 & 123.16 & 200.18 & 112.29 & 133.51 \\
\hline & Total & 481.27 & 1855.48 & 424.64 & 670.16 & 1354.44 & 1023.87 & 409.43 & 717.74 & 1371.80 & 830.71 & 210.85 & 394.93 & 336.01 & 190.04 \\
\hline \multirow{2}{*}{ MAY } & Variable & 270.58 & 333.30 & 224.78 & 269.42 & 427.50 & 307.46 & 233.95 & 282.01 & 321.96 & 332.97 & 134.24 & 227.19 & 111.63 & 134.26 \\
\hline & Total & 538.82 & 1006.39 & 424.10 & 772.32 & 1510.40 & 728.47 & 403.56 & 714.67 & 1248.32 & 837.32 & 195.51 & 416.67 & 259.51 & 186.19 \\
\hline \multirow{2}{*}{ JUN } & Variable & 260.64 & 321.89 & 226.94 & 255.39 & 392.43 & 303.33 & 226.25 & 262.95 & 264.66 & 297.31 & 144.12 & 228.09 & 116.75 & 143.14 \\
\hline & Total & 497.31 & 905.21 & 370.35 & 472.62 & 1452.95 & 634.68 & 360.61 & 581.66 & 808.42 & 801.54 & 210.22 & 411.98 & 237.42 & 192.00 \\
\hline \multirow{2}{*}{ JUL } & Variable & 248.50 & 309.36 & 225.48 & 241.46 & 363.81 & 286.59 & 227.82 & 286.54 & 261.06 & 294.73 & 158.41 & 229.77 & 104.20 & 146.27 \\
\hline & Total & 478.78 & 1238.33 & 334.89 & 358.79 & 1196.73 & 592.86 & 357.90 & 705.40 & 605.95 & 594.81 & 206.08 & 361.24 & 181.17 & 183.89 \\
\hline \multirow{2}{*}{ AUG } & Variable & 253.07 & 294.95 & 218.03 & 243.57 & 359.86 & 303.43 & 221.10 & 306.53 & 248.82 & 257.32 & 142.99 & 215.57 & 104.94 & 145.66 \\
\hline & Total & 549.02 & 893.97 & 274.79 & 378.79 & 1083.91 & 517.70 & 309.67 & 609.19 & 573.91 & 442.28 & 182.13 & 317.84 & 166.32 & 176.27 \\
\hline \multirow{2}{*}{ SEP } & Variable & 255.21 & 312.77 & 218.11 & 235.24 & 362.96 & 299.04 & 222.73 & 307.37 & 243.29 & 297.77 & 128.49 & 217.34 & 106.65 & 145.52 \\
\hline & Total & 718.07 & 986.20 & 335.02 & 550.37 & 1202.45 & 795.58 & 324.44 & 777.04 & 761.79 & 701.59 & 179.53 & 355.56 & 189.09 & 180.45 \\
\hline \multirow{2}{*}{ NOV } & Variable & 250.69 & 314.22 & 214.49 & 270.89 & 397.48 & 427.54 & 253.10 & 294.87 & 293.85 & 311.79 & 101.78 & 212.88 & 102.74 & 133.77 \\
\hline & Total & 524.03 & 897.81 & 400.46 & 582.70 & 1417.60 & 1068.78 & 471.98 & 642.49 & 1152.87 & 884.28 & 217.51 & 379.49 & 274.74 & 188.53 \\
\hline \multirow{2}{*}{ DEC } & Variable & 253.45 & 271.69 & 217.66 & 268.55 & 355.55 & 381.50 & 222.13 & 283.47 & 312.68 & 285.75 & 103.06 & 218.97 & 103.16 & 132.37 \\
\hline & Total & 490.59 & 718.38 & 424.10 & 803.38 & 1463.11 & 1178.03 & 392.27 & 728.10 & 1268.85 & 894.64 & 200.13 & 363.57 & 246.28 & 180.11 \\
\hline
\end{tabular}

\begin{tabular}{|c|c|c|c|c|c|c|c|c|c|c|c|c|c|c|c|}
\hline & & Kythnos & $\begin{array}{c}\text { Kos- } \\
\text { Kalymnos }\end{array}$ & Lesvos & Lemnos & Megisti & Milos & Mykonos & Othoni & Paros & Patmos & Rhodes & Samos & Serifos & Sifnos \\
\hline \multirow{2}{*}{ JAN } & Variable & 228.99 & 95.45 & 116.59 & 112.48 & 273.69 & 101.87 & 225.30 & 341.90 & 101.54 & 231.33 & 125.42 & 105.78 & 230.57 & 227.11 \\
\hline & Total & 392.23 & 153.67 & 151.40 & 182.54 & 448.91 & 210.08 & 334.27 & 726.03 & 153.62 & 313.33 & 185.75 & 168.78 & 376.75 & 364.94 \\
\hline \multirow{2}{*}{ FEB } & Variable & 231.19 & 98.74 & 114.15 & 113.30 & 280.43 & 103.00 & 232.46 & 301.94 & 104.14 & 230.05 & 143.37 & 107.18 & 224.59 & 230.16 \\
\hline & Total & 402.20 & 175.22 & 153.93 & 194.04 & 507.56 & 227.98 & 355.52 & 749.54 & 179.96 & 331.56 & 219.53 & 182.64 & 378.64 & 395.97 \\
\hline \multirow{2}{*}{ MAR } & Variable & 234.63 & 104.88 & 103.19 & 108.75 & 274.89 & 98.00 & 225.91 & 358.29 & 100.95 & 216.89 & 128.28 & 99.42 & 222.66 & 217.13 \\
\hline & Total & 399.33 & 182.47 & 158.55 & 186.08 & 511.06 & 214.00 & 343.03 & 848.14 & 159.87 & 310.43 & 203.81 & 173.57 & 373.39 & 376.30 \\
\hline \multirow{2}{*}{ APR } & Variable & 185.26 & 95.06 & 94.69 & 114.64 & 250.07 & 83.17 & 228.59 & 325.54 & 97.05 & 217.98 & 121.42 & 100.12 & 177.96 & 176.22 \\
\hline & Total & 310.87 & 173.35 & 148.21 & 221.81 & 575.21 & 189.68 & 329.62 & 906.14 & 156.79 & 329.96 & 203.79 & 187.98 & 312.93 & 301.79 \\
\hline MAY & Total & 435.64 & 139.50 & 165.09 & 217.28 & 487.96 & 200.88 & 304.11 & 742.54 & 160.92 & 325.41 & 190.62 & 188.03 & 405.51 & 361.94 \\
\hline
\end{tabular}




\section{Continued}

\begin{tabular}{cccccccccccccccc}
\hline \multirow{2}{*}{ JUN } & Variable & 222.43 & 91.19 & 99.96 & 105.68 & 264.48 & 92.25 & 230.01 & 345.31 & 95.44 & 233.14 & 132.73 & 96.37 & 226.26 & 224.92 \\
& Total & 402.39 & 137.18 & 171.27 & 206.85 & 496.65 & 193.54 & 298.25 & 846.16 & 142.04 & 347.02 & 180.71 & 185.92 & 400.94 & 349.63 \\
\multirow{2}{*}{ JUL } & Variable & 222.03 & 92.86 & 100.24 & 103.50 & 257.85 & 90.80 & 231.11 & 311.15 & 103.74 & 216.78 & 139.21 & 90.19 & 221.85 & 224.56 \\
& Total & 387.02 & 124.86 & 147.29 & 181.10 & 391.87 & 168.63 & 277.33 & 604.71 & 135.13 & 288.68 & 173.92 & 154.53 & 308.21 & 302.85 \\
\multirow{2}{*}{ AUG } & Variable & 221.12 & 99.83 & 95.75 & 101.50 & 269.06 & 89.82 & 227.56 & 287.98 & 102.85 & 218.24 & 154.33 & 94.33 & 221.05 & 218.97 \\
& Total & 306.53 & 125.68 & 129.03 & 157.38 & 356.82 & 152.16 & 260.88 & 459.08 & 128.06 & 264.64 & 186.41 & 150.85 & 307.02 & 276.28 \\
\multirow{2}{*}{ SEP } & Variable & 225.29 & 95.92 & 92.90 & 105.97 & 242.32 & 92.67 & 221.85 & 322.93 & 97.91 & 215.62 & 135.04 & 95.97 & 222.11 & 217.68 \\
& Total & 399.65 & 129.53 & 141.07 & 191.12 & 376.61 & 175.27 & 266.83 & 674.17 & 141.36 & 289.12 & 167.50 & 168.48 & 359.83 & 314.67 \\
\multirow{2}{*}{ OCT } & Variable & 226.62 & 87.44 & 95.34 & 103.07 & 254.10 & 92.97 & 220.24 & 401.41 & 93.88 & 218.35 & 112.77 & 97.82 & 230.01 & 223.30 \\
& Total & 429.79 & 131.91 & 137.59 & 182.44 & 546.70 & 195.04 & 289.02 & 979.01 & 147.28 & 317.43 & 152.78 & 195.33 & 408.44 & 417.81 \\
\multirow{2}{*}{ NOV } & Variable & 220.53 & 88.41 & 98.57 & 103.79 & 270.10 & 93.32 & 215.98 & 397.13 & 90.02 & 215.55 & 105.86 & 93.22 & 221.34 & 219.44 \\
& Total & 437.16 & 169.71 & 146.82 & 210.77 & 536.69 & 203.72 & 343.85 & 932.10 & 175.03 & 334.26 & 191.52 & 180.08 & 429.08 & 391.05 \\
\multirow{2}{*}{ DEC } & Variable & 228.76 & 88.82 & 99.09 & 103.04 & 220.74 & 92.32 & 221.80 & 356.86 & 89.60 & 212.46 & 101.36 & 89.34 & 211.62 & 216.70 \\
& Total & 504.87 & 156.71 & 137.36 & 194.76 & 458.00 & 215.42 & 327.03 & 933.90 & 156.89 & 308.30 & 168.56 & 162.15 & 469.13 & 407.61 \\
\hline
\end{tabular}

\begin{tabular}{|c|c|c|c|c|c|}
\hline & & Skyros & Symi & Syros & Chios \\
\hline \multirow{2}{*}{ JAN } & Variable & 216.27 & 232.24 & 105.35 & 95.94 \\
\hline & Total & 332.52 & 329.78 & 172.84 & 140.73 \\
\hline \multirow{2}{*}{ FEB } & Variable & 226.58 & 229.87 & 109.37 & 99.28 \\
\hline & Total & 362.32 & 360.90 & 193.33 & 155.39 \\
\hline \multirow{2}{*}{ MAR } & Variable & 224.87 & 219.87 & 105.13 & 96.09 \\
\hline & Total & 359.50 & 309.89 & 190.17 & 152.86 \\
\hline \multirow{2}{*}{ APR } & Variable & 230.93 & 231.52 & 102.07 & 96.37 \\
\hline & Total & 385.30 & 405.80 & 206.61 & 174.81 \\
\hline \multirow{2}{*}{ MAY } & Variable & 227.98 & 227.13 & 104.54 & 96.38 \\
\hline & Total & 392.61 & 351.23 & 206.54 & 177.07 \\
\hline \multirow{2}{*}{ JUN } & Variable & 222.72 & 227.36 & 104.30 & 91.62 \\
\hline & Total & 389.48 & 352.14 & 203.08 & 166.48 \\
\hline \multirow{2}{*}{ JUL } & Variable & 222.41 & 250.63 & 104.40 & 89.04 \\
\hline & Total & 313.96 & 384.24 & 183.57 & 147.62 \\
\hline \multirow{2}{*}{ AUG } & Variable & 215.98 & 219.17 & 98.65 & 88.44 \\
\hline & Total & 286.41 & 275.27 & 166.02 & 132.85 \\
\hline \multirow{2}{*}{ SEP } & Variable & 213.75 & 215.89 & 101.59 & 89.88 \\
\hline & Total & 346.83 & 337.18 & 189.13 & 151.59 \\
\hline \multirow{2}{*}{ OCT } & Variable & 222.73 & 229.73 & 103.07 & 91.56 \\
\hline & Total & 447.33 & 368.01 & 190.65 & 156.17 \\
\hline \multirow{2}{*}{ NOV } & Variable & 218.44 & 218.36 & 98.11 & 89.46 \\
\hline & Total & 362.79 & 368.53 & 193.12 & 151.44 \\
\hline \multirow{2}{*}{ DEC } & Variable & 213.54 & 214.95 & 98.45 & 85.16 \\
\hline & Total & 342.34 & 346.81 & 183.72 & 134.26 \\
\hline
\end{tabular}


Table S3. Investment, operation and maintenance costs used in the energy simulations.

\begin{tabular}{|c|c|c|c|c|}
\hline Type of technology & Investment cost & $\begin{array}{c}\text { Replacement } \\
\text { cost }\end{array}$ & $\begin{array}{l}\text { Operation and } \\
\text { maintenance cost }\end{array}$ & Fuel cost \\
\hline Photovoltaic panels & $700 € / \mathrm{kW}$ & $550 € / \mathrm{kW}$ & $21 € / \mathrm{kW} /$ year & - \\
\hline Wind generators (nominal power $25 \mathrm{~kW}$ ) & $61,250 € / \mathrm{pc}$ & $55,000 € / \mathrm{pc}$ & $1225 € /$ pc/year & - \\
\hline Small Hydro Turbine (nomilal power $80 \mathrm{~kW}$ ) & $108,000 € / \mathrm{pc}$ & $90,000 € / \mathrm{pc}$ & $4320 € /$ pc/year & - \\
\hline Batteries Li-Ion (capacity $100 \mathrm{kWh}$ ) & $70,000 € / \mathrm{pc}$ & $30,000 € / \mathrm{pc}$ & $1000 € / \mathrm{pc} /$ year & - \\
\hline $\begin{array}{l}\text { Batteries Li-Ion (capacity } 100 \mathrm{kWh}) \\
\text { Low cost scenario }\end{array}$ & $30,000 € / \mathrm{pc}$ & $10,000 € / \mathrm{pc}$ & $1000 € /$ pc/year & - \\
\hline Converter DC/AC & $250 € / \mathrm{kW}$ & $230 € / \mathrm{kW}$ & - & - \\
\hline Diesel electro generator & $-*$ & $1200 € / \mathrm{kW}$ & $0.05 € /$ oper. $\mathrm{h}$ & $0.60 € /$ lit diesel \\
\hline
\end{tabular}

*The investment cost of diesel generators has been neglected, since there are already installed in the island. So, only replacement costs have been considered.

Table S4. Renewable energy potential in Astypalea.

\begin{tabular}{ccccc}
\hline Month & Clearance Index & $\begin{array}{c}\text { Daily Radiation } \\
\left(\mathrm{kWh} / \mathrm{m}^{2} / \text { day }\right)^{*}\end{array}$ & $\begin{array}{c}\text { Average Wind } \\
\text { Speed }(\mathrm{m} / \mathrm{sec})^{*}\end{array}$ & $\begin{array}{c}\text { Volumetric Water } \\
\text { flow (lit/sec) })^{* *}\end{array}$ \\
\hline JAN & 0.497 & 2.400 & 6.910 & 300 \\
FEB & 0.529 & 3.270 & 7.580 & 300 \\
MAR & 0.578 & 4.650 & 6.530 & 300 \\
APR & 0.619 & 6.100 & 5.740 & 200 \\
MAY & 0.670 & 7.420 & 5.080 & 200 \\
JUN & 0.721 & 8.340 & 5.160 & 150 \\
JUL & 0.739 & 8.350 & 6.240 & 150 \\
AUG & 0.731 & 7.520 & 5.760 & 150 \\
SEP & 0.711 & 6.150 & 5.360 & 100 \\
OCT & 0.649 & 4.360 & 5.700 & 200 \\
NOV & 0.547 & 2.800 & 6.170 & 300 \\
DEC & 0.467 & 2.060 & 6.630 & 300 \\
\hline
\end{tabular}

${ }^{*}$ Based on HOMER libraries that follow NASA meteorology and solar energy database, ${ }^{*}$ Based on assumptions from data retrieved by Daniil (2018). 